NBER WORKING PAPER SERIES

\title{
FINANCIAL CONSTRAINTS AND INNOVATION: WHY POOR COUNTRIES DON'T CATCH UP
}

\author{
Yuriy Gorodnichenko \\ Monika Schnitzer \\ Working Paper 15792 \\ http://www.nber.org/papers/w15792
NATIONAL BUREAU OF ECONOMIC RESEARCH
1050 Massachusetts Avenue
Cambridge, MA 02138 \\ March 2010
}

We would like to thank Bronwyn Hall, Dietmar Harhoff, Bill Kerr, Klara Sabirianova Peter, John van Reenen, Oleksandr Talavera, and Joachim Winter as well as seminar participants at NBER, SFB-TR, University of Linz and University of Munich for comments and suggestions. This paper was partly written while Monika Schnitzer visited the University of California, Berkeley. She gratefully acknowledges the hospitality of the department as well as financial support by the German Science Foundation through SFB-TR 15. Gorodnichenko thanks NBER (Innovation Policy and the Economy program) for financial support. The views expressed herein are those of the authors and do not necessarily reflect the views of the National Bureau of Economic Research.

NBER working papers are circulated for discussion and comment purposes. They have not been peerreviewed or been subject to the review by the NBER Board of Directors that accompanies official NBER publications.

(C) 2010 by Yuriy Gorodnichenko and Monika Schnitzer. All rights reserved. Short sections of text, not to exceed two paragraphs, may be quoted without explicit permission provided that full credit, including $\odot$ notice, is given to the source. 
Financial constraints and innovation: Why poor countries don't catch up

Yuriy Gorodnichenko and Monika Schnitzer

NBER Working Paper No. 15792

March 2010

JEL No. F1,G3,O16,O3

\begin{abstract}
$\underline{\text { ABSTRACT }}$
This paper examines micro-level channels of how financial development can affect macroeconomic outcomes like the level of income and export intensity. We investigate theoretically and empirically how financial constraints affect a firm's innovation and export activities, using unique firm survey data which provides direct measures for innovations and firm-specific financial constraints. We find that financial constraints restrain the ability of domestically owned firms to innovate and export and hence to catch up to the technological frontiers. This negative effect is amplified as financial constraints

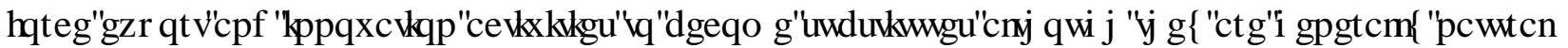
complements.
\end{abstract}

Yuriy Gorodnichenko

Department of Economics

549 Evans Hall \#3880

University of California, Berkeley

Berkeley, CA 94720-3880

and NBER

ygorodni@econ.berkeley.edu

Monika Schnitzer

Department of Economics, University of Munich,

Akademiestr. 1/III,

80799 Munich, Germany

schnitzer@1rz.uni-muenchen.de 


\section{Introduction}

One of the central questions in economic growth and development is why disparities in income and development across countries are large and persistent, despite increasing globalization. Much of empirical and theoretical research has been developed to identify factors that prevent less developed countries from catching up with developed countries. After decades of research, however, the question continues to puzzle the profession. Most of the difference in income across countries is attributed to differences in productivity which, in words of Zvi Griliches, is a measure of our ignorance. In this paper, we attempt to shed more light onto what determines variation in the level of productivity and hence income across countries by better understanding frictions that prevent firms from innovation as well as other productivity enhancing activities such as exporting goods and, consequently, from catching up.

We focus on a prominent theory advocating that cross-country differences in credit market development considerably contribute to cross-country differences in incomes and productivity (see e.g. Banerjee and Duflo (2005) and Levine (2005) for surveys). Indeed, there is ample macroeconomic evidence that the development of financial markets is strongly correlated with the development of a country. Although microeconomic channels for this relationship are an area of active research, many aspects of micro-level determinants remain unclear. The lack of micro-level evidence is particularly striking for non-OECD countries and for dynamic aspects of productivity gains such as innovation flows.

One stylized fact that appears from emerging markets and transition economies though is that foreign owned firms tend to be more productive than domestically owned firms and these productivity differences between domestically and foreign owned firms do not seem to diminish over time (Blomstrom (1988), Haddad and Harrison (1993), Aitken and Harrison (1999), Arnold and Javorcik (2009), Estrin et al. (2009)). ${ }^{1}$ To the extent that foreign owned firms embody the technological frontier, one can interpret this fact as suggesting that some forces prevent domestically owned firms from emulating the best practices and techniques. Stylized facts from OECD countries point to what these forces might be. Financial frictions affect investment as well as research and development (R\&D) spending made by firms at the microeconomic level (see Hall (2002) and Hall and Lerner (2009) for surveys). Furthermore, financial frictions tend to adversely affect a firm's ability to export (e.g., Greenaway et al. (2007)). Since, exporting firms are more productive than non-exporting firms (e.g. Bernard and Jensen (1999)) which in part could be attributed to export stimulating productivity enhancements (e.g. Van Biesebroeck (2005) and De Loecker (2007)), financial constraints can prevent firms from realizing gains from trade liberalization which should foster productivity growth.

\footnotetext{
${ }^{1} \mathrm{~A}$ part of the discrepancy in the levels of productivity of domestically and foreign owned firms could be due to selection effects when only most productive firms establish subsidiaries abroad or when foreign owners purchase only most productive domestically owned firms. However, even after controlling for such effects (Estrin et al. (2009)), the difference between domestically and foreign owned firms remains large and persistent.
} 
We explore these micro-channels in a stylized theoretical framework where firms make decisions about whether to innovate and/or to export given financial constraints. We show that a firm's decision to invest into innovative and exporting activities is sensitive to financial frictions which can prevent firms from developing and adopting better technologies. Furthermore, we demonstrate that in a world without financial frictions, innovation and exporting goods are complementary activities. Thus, easing financial frictions can have an amplified effect on firms' innovation effort and consequently the level of productivity. However, as financial frictions become increasingly severe, these activities become effectively substitutes since both exporting and innovation rely on internal funds of firms.

We test predictions of our model using Business Environment and Enterprise Performance Surveys (BEEPS) which covers a broad array of sectors and countries in Eastern Europe and Commonwealth of Independent States (CIS). As we argue below, this data set has a number of advantages relative to data sets used in previous research. Most importantly, BEEPS collects direct measures of innovation and financial constraints so that we do not have to rely on indirect proxies for the key variables in our analysis. In addition, BEEPS provides information on shocks to firms' cash flow and internal funds which we can use as firm-level instrumental variables for our measures of financial constraints. We document that these self-reported measures are strongly correlated with more objective macroeconomic indicators of financial development.

Our preferred econometric results based on instrumental variable estimates unambiguously suggest that innovative activities of firms are strongly influenced by financial frictions. Moreover, we show that domestically owned firms are more likely to be affected by financial constraints than foreign firms, which helps explain why domestically owned firms do not catch up. We also find that financial frictions affect export status and, consistent with our theoretical predictions, the joint incidence of export and innovation activities decreases in the severity of financial constraints. This may explain why the integration of product markets does not necessarily help domestically owned firms to catch up. Finally, we document that financial frictions measured at the firm level are strongly negatively correlated with macroeconomic measures for productivity and trade intensity. Thus, our analysis suggests financial frictions adversely affecting innovation as one potential microeconomic channel restraining macroeconomic productivity and growth.

These findings point to clear policy prescriptions. To boost productivity at micro and macro levels, policymakers should focus on developing financial markets that ensure access to external funding for a broad array of firms. Reducing the cost of as well as enhancing access to external finance is likely to lead to more intensive innovation and exporting activities which, in turn, are likely to yield a rapid development of new goods and technologies and adoption of frontier technologies and practices. ${ }^{2}$ Otherwise, costly external funding due to poor access or excessively

\footnotetext{
${ }^{2}$ More intensive innovation is unlikely to decrease welfare (e.g. due to duplication of efforts) in BEEPS countries since innovation in developing and transition economies is primarily about adopting technologies existing in developed countries.
} 
high interest rates may significantly hamper convergence to the technological frontier.

Our analysis builds on and contributes to three broad strands of previous research. First, we contribute to a large literature documenting effects of financial frictions on R\&D expenditures in OECD countries. ${ }^{3}$ More recently this literature has started to shift focus on direct measures of innovation rather than indirect ones such as R\&D spending. Ayyagari et al. (2007), which is the closest to our analysis, study the determinants of broadly defined innovation (i.e., innovation is not only product and process innovation, but also closing plants, entering a joint venture, obtaining a new licensing agreement and others) using survey data from 47 developing countries. Similar to our results, Ayyagari et al. (2007) find a positive relationship between the use of external finance and the extent of innovation. Our paper is different from Ayyagari et al. (2007) in several important respects. First, we consider the interplay between export and innovation. Second, we use a direct measure of financial constraints based on reported difficulties in access to external finance rather than the actual use of external finance to finance investment which does not adequately reflect how firms intended to finance their investment and would not be informative if investments do not occur due to financial constraints. Third, we use time-varying firm-level rather than time-invariant country-level instrumental variables to address potential endogeneity of access to external finance. Using instruments at the firm level is important for two reasons: $i$ ) using time-invariant countrylevel instruments (e.g., legal origin) effectively amounts to running regressions with data aggregated to country level and thus is vulnerable to shocks affecting access to external finance at the country level; ii) firm-level variation dwarfs variation at the country level and hence using country-level instruments may capture only a small fraction of variation so that estimates may be imprecise and may measure the causal effect only due to country-level variation rather than quantitatively more important firm-level variation. Finally, we also provide a theoretical rationale why access to external finance may matter for innovation, even though most firms report to rely exclusively on internal finance for their innovation activities.

The second strand reports that financial frictions influence a firm's ability to export. For example, Chaney (2005) introduces financial constraints into Melitz (2003) model and predicts that financially constrained firms are less likely to cover the fixed costs of exporting and hence less likely to export. In line with Chaney's predictions, data on bilateral export flows imply

\footnotetext{
${ }^{3}$ Early papers in this literature exploited the idea that a change in available internal funds should not affect investment or $\mathrm{R} \& \mathrm{D}$ expenditure, if firms are not limited in their access to external funds. This hypothesis was tested by examining the sensitivity of investment and R\&D spending to cash flow variables in the standard Eulertype investment regressions (The rationale of this approach has been challenged by Kaplan and Zingales (2000)). Himmelberg and Petersen (1994) were the first to find an economically large and statistically significant relationship between R\&D expenditure and internal finance for a panel of small high-tech firms. Similarly, Mulkay et al. (2001) compare the cash flow sensitivity of both $R \& D$ expenditure and capital investment for US and French firms. They report that cash flow has a much larger impact on both R\&D and investment in the US than in France. They also find no significant difference between the sensitivity of investment and R\&D expenditure to measures of financial constraints. Bond et al. (2006) compare firm level panel data from the UK and Germany providing evidence that suggests that financial constraints are more relevant for British firms than for German firms. See Hall and Lerner (2009) for a review.
} 
that financially more developed countries are more likely to export and that the effect is more pronounced in financially vulnerable sectors (Manova (2008)). Micro-level data studies, which typically rely on firms' balance sheets and income statements to capture financial constraints, also broadly support these predictions. For instance, Bellone et al. (2008) find that export starters enjoy better financial conditions while Greenaway et al. (2007) and Buch et al. (2009) report that financially healthy firms are more likely to export. ${ }^{4}$

The final strand is the nascent literature investigating the interaction between export and innovation. Most of this literature is theoretical (Atkeson and Burstein (2007), Constantini and Melitz (2008)) and aimed to show that adoption of new technologies in a country is more likely to occur after trade liberalization. Consistent with these theoretical models, Bustos (2007) finds that new entrants in the export market upgraded technology faster than other firms after trade and capital account liberalization in the early 1990s in Argentina. The dearth of empirical evidence in this literature makes our results particularly valuable, even more so as the impact of financial constraints has not yet been taken into account in this literature. We also emphasize in our theoretical model that if financial constraints are severe, innovation and export activities are less likely to be complements and may appear to be substitutes instead.

The paper is organized as follows. Section 2 lays out a stylized model of a firm's decision to innovate and to export when faced with financial constraints. Section 3 describes the data and Section 4 presents the econometric specification. In Section 5 we report the main empirical findings. Section 6 concludes with a discussion of how one can use our findings to reconcile the stylized facts presented above and of ensuing policy implications.

\section{Theoretical Framework}

In this section we develop a stylized model to highlight the interaction between financial constraints, innovation and exporting activities. We abstract from many details to present a clear picture of how these three phenomena are interconnected. We will use this prototypical model to derive a series of falsifiable implications which we will test later in the empirical sections of the paper.

\subsection{Basic Setup}

Consider an investor who has the opportunity to invest in innovation activities, at a fixed cost $F_{I}$, before engaging in production. ${ }^{5}$ Since the focus of our analysis is the impact of financial

\footnotetext{
${ }^{4}$ The micro-level evidence however is not unanimous. Stiebale (2008) finds no effect of financial constraints on a firm's export decision once observed and unobserved financial firm heterogeneity is accounted for.

${ }^{5}$ In principle, the innovation can take two forms: product innovation and process innovation. For the purpose of our analysis, however, it is not necessary to distinguish these two forms: to fix ideas, we assume that both forms of innovation increase the firm's profit potential by the same amount.
} 
constraints on the investor's innovation activities, we need to specify in some detail how innovation and production are financed. In principle, the investor can use either internal funds resulting from previous cash flows or external funding obtained from creditors to finance current expenditures. We assume that external funding is more expensive than internal due to asymmetric information problems. Specifically, to finance one unit of credit the investor has to pay $\gamma>1$ for external financing while the opportunity cost of internal financing is normalized to $1 .{ }^{6}$

Consistent with the empirical evidence (e.g. Hall and Lerner (2009), Ughetto (2008)), we assume that to finance innovation at stage 1, the investor has to rely on internal funds from positive cash flows. Intuitively, innovation is an activity which is particularly prone to asymmetric information problems and that cannot be easily collateralized. This rules out using external finance for innovation.

At stage 2, production needs to be financed. The firm prefers to use internal finance for production, if possible, but needs to turn to external sources if internal funds are not sufficient. We assume that a priori, sufficient internal funds for production will be available with probability $q$, while external finance needs to be used with probability $(1-q)$.

We capture financial constraints by the likelihood with which the firm needs to rely on external financing. There are two kinds of events that can increase the likelihood of the need to rely on external finance. First of all, the investor may spend internal funds on innovation activities at stage 1, which leaves less internal funds for production at stage 2 . In this case, the likelihood of having sufficient internal funds is lowered by $\delta_{I}$. Furthermore, the investor may experience a shock to liquidity, due to late payments by customers, for instance. This lowers the likelihood of having sufficient internal funds by $\delta_{L} \in\left\{0, \overline{\delta_{L}}\right\}$. While the investor can influence the first kind of events, by choosing whether or not to innovate, we assume that he has no influence on the second kind of events.

Both cases imply that the investor has to rely on external finance with larger probability. It is in these cases that the investor will feel financially constrained, because he realizes that he needs external finance which may be difficult or very costly to obtain. ${ }^{7}$ Since innovation reduces the amount of internal funds, it increases the probability of hitting financial constraints and thus one may observe in the data that incidences of innovations and reported severity of financial constraints are positively correlated. Exogenous shocks to internal funds, on the other hand, are unaffected by innovation activities and hence this source of variation can be used later as an instrumental variable.

In summary, the sequence of events is as follows. In stage 0, the potential exogenous shock to liquidity, $\delta_{L} \in\left\{0, \overline{\delta_{L}}\right\}$, is realized. In stage 1 , the investor considers whether or not to innovate.

\footnotetext{
${ }^{6}$ The cost $\gamma$ absorbs not only the direct cost of credit from external sources but also indirect costs associated with external credit being unavailable.

${ }^{7}$ It is straightforward to extend our theoretical analysis to including the case where a negative liquidity shock $\delta_{L}$ has a positive impact on the cost $\gamma$ at which external finance can be attracted. This reinforces the negative impact of a negative liquidity shock on the incentive to innovate.
} 
Let $\pi_{i}$ denote the profit if no innovation takes place where $i=0$ if production is financed with internal funds and $i=\gamma$ if it is financed externally, with $\pi_{0}>\pi_{\gamma}$. Similarly, let $\pi_{i}^{I}$ denote the profit if the investor has carried out an innovation, with $\pi_{i}^{I}>\pi_{i}$. Without loss of generality, we assume that the increase in profit resulting from innovation decreases as the cost of financing increases, i.e.

\section{Assumption 1}

$$
\frac{d\left(\pi_{\gamma}^{I}-\pi_{\gamma}\right)}{d \gamma}<0
$$

In the appendix, we show this assumption to hold for a standard model of monopolistic competition.

Ex ante, the investor's expected payoff if he does not innovate is

$$
E(\pi)=\left(q-\delta_{L}\right) \pi_{0}+\left(1-q+\delta_{L}\right) \pi_{\gamma}
$$

If the investor spends internal funds on innovation at stage 1, production can be financed internally at stage 2 with probability $q-\delta_{L}-\delta_{I}$, while with probability $\left(1-q+\delta_{L}+\delta_{I}\right)$ external finance has to be used. In case of innovation, the ex ante expected profit is

$$
E(\pi \mid I)=\left(q-\delta_{L}-\delta_{I}\right) \pi_{0}^{I}+\left(1-q+\delta_{L}+\delta_{I}\right) \pi_{\gamma}^{I}-F_{I}
$$

At stage 2, production takes place and profits are realized.

We can now determine the investor's incentive to innovate at stage 1 and how this is affected by potential financial constraints arising from negative liquidity shocks at stage 0 . His incentive to innovate is given by the difference in expected profits:

$$
\begin{aligned}
\Delta_{\pi}^{I} & \equiv E(\pi \mid I)-E(\pi) \\
& =\left(q-\delta_{L}\right)\left(\pi_{0}^{I}-\pi_{0}\right)+\left(1-q+\delta_{L}\right)\left(\pi_{\gamma}^{I}-\pi_{\gamma}\right)-\delta_{I}\left(\pi_{0}^{I}-\pi_{\gamma}^{I}\right)-F_{I} .
\end{aligned}
$$

Naturally, a firm decides to innovate if and only if $\Delta_{\pi}^{I}>0$. To determine the impact of exogenous liquidity shocks, we take the first derivative of $\Delta_{\pi}^{I}$ with respect to $\delta_{L}$.

$$
\frac{d \Delta_{\pi}^{I}}{d \delta_{L}}=-\left(\pi_{0}^{I}-\pi_{0}\right)+\left(\pi_{\gamma}^{I}-\pi_{\gamma}\right)<0 .
$$

which follows from Assumption 1. Thus, the more severely the firm is hit by an exogenous liquidity shock, the less likely it is to innovate.

In the next step we examine how the impact of financial constraints is affected by the cost of external finance. We find that

$$
\frac{d^{2} \Delta_{\pi}^{I}}{d \delta_{L} d \gamma}=\frac{d\left(\pi_{\gamma}^{I}-\pi_{\gamma}\right)}{d \gamma}<0
$$

Thus, the larger $\gamma$, i.e. the larger the cost of external finance, the more damaging is the effect of a negative liquidity shock on the incentive to innovate. Note that although innovation is always 
financed internally, the cost of external finance matters for the innovation incentive. This is due to the fact that external finance may play a role for the production cost and hence for the overall profitability of the firm. Thus, the larger the cost of external finance, i.e. the smaller $\left(\pi_{\gamma}^{I}-\pi_{\gamma}\right)$, the more detrimental it is to rely on external finance and hence the more negative the impact of a negative liquidity shock is on the firm's innovation activities.

Although in this section we focus on innovation as a productivity enhancing activity which cannot be collateralized, we can extend our analysis to other types of activities which cannot be easily collateralized yet lead to improvements in measured productivity. A prominent example of such alternative activities is exporting goods. The sunk and flow cost of exporting goods often do not have a significant material component (e.g., a building or machine) and thus is similar to innovation in this respect. Likewise, exporting goods expands the market size so that overhead costs can be spread more widely and hence an exporting firm can be more productive. Therefore, one may reasonably use our model to study exporting as well and it is straightforward to repeat our analysis from above to show that the incentive to engage in exporting decreases as the availability of internal funds decreases, i.e. $\delta_{L}$ increases. $^{8}$

\subsection{Interaction of export and innovation}

In this section we investigate how financial constraints affect the interaction of a firm's activities that draw on scarce financial resources. For this purpose, consider the entry to a foreign market as a second activity the firm may be interested in. As in Melitz (2003), setting up exporting facilities requires an upfront investment $F_{E} \cdot{ }^{9}$ Let $\pi_{i}^{I E}$ denote the profit if both activities are carried out and $\pi_{i}^{E}$ denote the profit if only exporting is chosen as a new activity, with $i=\{0, \gamma\}$, depending on how production is financed.

Since returns to innovation increase in the size of the market, exporting (i.e., entering a new market) makes innovation more attractive. On the other hand, a more productive firm (i.e., a firm which has innovated successfully) gains more from exporting than a less productive firm. Hence, innovation and entering a new market are complements. To capture this pattern, we make the following assumption.

\section{Assumption 2}

$$
\begin{aligned}
\pi_{i}^{I E}-\pi_{i}^{I} & >\pi_{i}^{E}-\pi_{i} \text { and } \\
\pi_{i}^{I E}-\pi_{i}^{E} & >\pi_{i}^{I}-\pi_{i}
\end{aligned}
$$

i.e. the incentive to invest in starting export activities is larger if the firm invests in innovation

\footnotetext{
${ }^{8}$ Although our partial equilibrium analysis provides a number of useful insights, it may miss some general equilibrium effects which can amplify or attenuate factors highlighted in our analysis. We leave analysis of these general equilibrium effects to future research.

${ }^{9}$ These fixed cost of entering a foreign market are the reason why only the most productive firms are internationally active, because only the most productive firms are able to shoulder the fixed cost of market entry.
} 
activities as well and vice versa. In the appendix, we illustrate that this assumption holds for a standard model of monopolistic competition.

Consider now the investor's incentive to invest in both innovation and exporting. If both activities need to be financed with internal funds, it is even less likely to have internal funds left to finance production than if only one activity is financed. Thus, the expected payoff is given by

$$
E(\pi \mid I E)=\left(q-\delta_{L}-\delta_{I E}\right) \pi_{0}^{I E}+\left(1-q+\delta_{L}+\delta_{I E}\right) \pi_{\gamma}^{I E}-F_{I}-F_{E}
$$

with $\delta_{I E} \geq \delta_{I}+\delta_{E}$. The incentive to engage in both activities is captured by the following difference in profits:

$$
\begin{aligned}
\Delta_{\pi}^{I E} & \equiv E(\pi \mid I E)-E(\pi) \\
& =\left(q-\delta_{L}\right)\left[\pi_{0}^{I E}-\pi_{0}\right]+\left(1-q+\delta_{L}\right)\left[\pi_{\gamma}^{I E}-\pi_{\gamma}\right]-\delta_{I E}\left[\pi_{0}^{I E}-\pi_{\gamma}^{I E}\right]-F_{I}-F_{E}
\end{aligned}
$$

Like in case of a single activity, the incentive to carry out both activities simultaneously reacts negatively to an exogenous liquidity shock, as captured by $\delta_{L}$.

$$
\frac{\Delta_{\pi}^{I E}}{d \delta_{L}}=-\left[\left(\pi_{0}^{I E}-\pi_{0}\right)-\left(\pi_{\gamma}^{I E}-\pi_{\gamma}\right)\right]<0
$$

It is interesting to study how the interaction of the two activities affects the incentive to carry out both rather than just one if a firm is financially constrained. Consider for example the incentive to invest in starting exporting activities if the firm has invested in innovation already, $E(\pi \mid I E)-$ $E(\pi \mid I)$, as compared to the incentive if the firm has not invested in innovation, $E(\pi \mid E)-E(\pi)$. Of course, if there is no extra cost of using external finance, i.e. $\pi_{\gamma}=\pi_{0}$ the incentives reduce to

$$
\begin{aligned}
E(\pi \mid I E)-E(\pi \mid I) & =\left[\pi_{0}^{I E}-F_{E}-F_{I}\right]-\left[\pi_{0}^{I}-F_{I}\right] \\
& >\left[\pi_{0}^{E}-F_{E}\right]-\left[\pi_{0}\right]=E(\pi \mid E)-E(\pi)
\end{aligned}
$$

if Assumption 2 holds. Thus, the incentive to invest in exporting if the firm has also invested in innovation is by definition larger than if the firm has not invested in innovation if the two are complements.

If external finance is costly, however, this need no longer be the case. To see this, we need to compare again $E(\pi \mid I E)-E(\pi \mid I)$ with $E(\pi \mid E)-E(\pi)$.

$$
\begin{aligned}
E(\pi \mid I E)-E(\pi \mid I) & =\left(q-\delta_{L}-\delta_{I E}\right) \pi_{0}^{I E}+\left(1-q+\delta_{L}+\delta_{I E}\right) \pi_{\gamma}^{I E}-F_{E}-F_{I} \\
- & {\left[\left(q-\delta_{L}-\delta_{I}\right) \pi_{0}^{I}+\left(1-q+\delta_{L}+\delta_{I}\right) \pi_{\gamma}^{I}-F_{I}\right] } \\
E(\pi \mid E)-E(\pi) & =\left(q-\delta_{L}-\delta_{E}\right) \pi_{0}^{E}+\left(1-q+\delta_{L}+\delta_{E}\right) \pi_{\gamma}^{E}-F_{E} \\
& -\left[\left(q-\delta_{L}\right) \pi_{0}+\left(1-q+\delta_{L}\right) \pi_{\gamma}\right]
\end{aligned}
$$

In the appendix we formally show that if the two activities are complementary the incentive to invest in exporting decreases more in $\delta_{L}$ if the firm has invested in innovation already than if it 
has not. We also formally show in the appendix that for financially constrained firms it is actually possible that the incentive to invest in exporting in addition to innovation is in fact smaller than the incentive would be without innovation, although they are complementary. Thus, for financially constrained firms they may appear to be substitutes, while for unconstrained firms they are complements. The intuition for this is that the larger the number of investments undertaken by the firm, the less internal funds are left for production. Thus, while an investment in innovation increases the profitability of an investment in exporting it also increases the likelihood of needing costly external finance which in turn makes exporting less attractive. This is more likely to be relevant, the more financially constrained the firm is, i.e. the larger the negative liquidity shock as captured by $\delta_{L}$ is. To summarize, the more severe the financial constraints, the more likely it is that the two activities appear to be substitutes while in fact they are complements.

\subsection{Empirical predictions}

We can now turn to the predictions implied by our theoretical framework. From equation (5) above, we can establish the following hypothesis.

Hypothesis 1 The more severe the financial constraints, as captured by the negative liquidity shock (larger $\left.\delta_{L}\right)$, the less likely it is that the firm engages in innovation or exporting activities.

Hypothesis 1 is the central prediction of our model. Effectively it states that a drain of internal funds is likely to make other activities (e.g. production or purchases of new machines) more expensive and, therefore, firms are less likely to do innovation or exporting.

From equation (6) we derive the next hypothesis.

Hypothesis 2 The larger are the cost of external finance (larger $\gamma$ ), the more negative is the impact of financial constraints on the firm's productivity enhancing activities such as export or innovation.

Hypothesis 2 suggests that financial constraints are likely to be more detrimental, the more expensive it is to finance export or innovation externally.

Finally, taking into account the interaction of the firm's decision to enter foreign markets and to innovate, we derive the following hypothesis.

Hypothesis 3 The more severe the financial constraints experienced by a firm, as captured by the negative liquidity shock (larger $\delta_{L}$ ), the relatively less likely it is to observe complementarities between exports and innovation, i.e. the relatively less likely it is that the firm chooses exports in addition to innovation (and vice versa) rather that than just one of the two activities.

According to Hypothesis 3, activities competing for the same internal funds become substitutes as internal funds become scarcer even when these activities are complements in absence of frictions. 


\section{Data}

To test the predictions outlined in the previous section, we use data from the 2002 and 2005 Business Environment and Enterprise Performance Survey (BEEPS), a joint initiative of the European Bank for Reconstruction and Development (EBRD) and the World Bank Group. These are large surveys of 6,500 firms in 2002 and 7,900 firms in 2005 in 27 transition countries. ${ }^{10}$ An important feature of this data set is the inclusion of firms in the service sector, which is the new dynamic (yet understudied) sector in these economies. The surveys relied on the same sampling frames and used identical questionnaires in all countries. To ensure that the samples are representative of the relevant population of firms, the surveys used stratified random sampling. For example, in each country, the sectoral composition of the sample in terms of manufacturing versus services was determined by their relative contribution to GDP. ${ }^{11}$ Firms that operate in sectors subject to government price regulation and prudential supervision, such as banking, electric power, rail transport, and water and waste water, were excluded from the sample. The sample includes very small firms with as few as two employees and firms with up to 10,000 employees. Moreover, the data include firms in the rural areas as well as large cities. Hence these data enable us to analyze diverse firms in a large number of countries. In addition, the data set contains a panel component, where 1,443 firms that were surveyed in 2002 were surveyed again in $2005 .{ }^{12}$ While we use these panel data for robustness checks, our analysis relies primarily on the pooled 2002 and 2005 data since many variables of interest have a retrospective component in each survey date and because it is hard to detect robust relationships with a small panel of heterogeneous firms, especially when we use many control variables.

In addition to basic information about firm characteristics such as age, employment size and composition, and degree of competition, BEEPS collects information on self-reported measures of access to finance. Specifically, firms are asked to report on a 1 ("No obstacle") to 4 ("Major obstacle") scale how problematic access to financing (e.g., collateral required or financing not available from banks) is for the operation and growth of the firm's business, hereafter Difficulty of Access to External Finance. Similar information is collected for the cost of financing (e.g., interest rates and charges), hereafter Cost of External Finance.

\footnotetext{
${ }^{10}$ In both years the surveys were administered to 15 countries from Central and Eastern Europe (Albania, Bosnia and Herzegovina, Bulgaria, Croatia, Czech Republic, Estonia, Serbia and Montenegro, Macedonia, Hungary, Latvia, Lithuania, Poland, Romania, Slovak Republic, and Slovenia), 11 countries from the former Soviet Union (Armenia, Azerbaijan, Belarus, Georgia, Kazakhstan, Kyrgyzstan, Moldova, Russia, Tajikistan, Ukraine and Uzbekistan) and Turkey. In neither year could the survey be administered in Turkmenistan. Our estimation sample includes only about 11,500 firms due to missing observations on variables on interest.

${ }^{11}$ Manufacturing includes: manufacturing and agro-processing. We do not include mining, quarrying and construction into manufacturing. Services includes: Transportation, storage and communications; wholesale, retail, repairs; real estate, business services; hotels and restaurants; other community, social and personal activities; and commerce.

${ }^{12}$ The relatively small size of the panel should not be associated with intensive exit of firms in these countries. The size of the panel is mainly brought about by a refusal of firms to participate in the new wave of the survey (42\%) and inability to reach eligible responders within firms $(25 \%)$.
} 
Since the self-reported measures of financial constraints may be distorted due to subjective or cultural biases, it is important to check whether these measures are correlated with alternative indicators especially at the macroeconomic level given our interest to explain cross-country differences in macroeconomic outcomes. Figure 1 plots the average score of reported difficulties with the cost of and access to external finance against indicators of financial development (private credit to GDP ratio and the net interest rate margin). The self-reported measures are clearly positively correlated with more objective macroeconomic indicators of financial development. In addition, since our analysis aims to explain the effect of financial constraints on export and innovation (and more generally productivity) at the micro level, we can explore if the average size of the frictions reported at the country level is correlated with macroeconomic outcomes and thus can reconcile the macroeconomic evidence that the development of financial markets is strongly correlated with the development of a country. Figure 2 confirms that reported financial constraints at the firm level show a strong negative correlation with macro-level measures for productivity and export intensity, which is consistent with previous studies based on macroeconomic data (Levine (2005), Lane (2009)). Thus, our measures of financial constraints are meaningful indicators of financial development at the country level and by explaining effects of variation in our measures of financial constraints we can shed new light on the sources of cross-country variation of income and productivity. $^{13}$

Finally, BEEPS asks firms to report various types of innovation activity. Hence, we are able to define innovation broadly as the development and upgrading of new products or adoption of new technologies. Specifically, we use binary variables based on answers to the question about whether firms have undertaken any of the following initiatives in the last three years: Developed successfully a major new product line or upgraded an existing product line - hereafter New Product; acquired new production technology - hereafter New Technology. These measures of innovation have several advantages over the more commonly used measures of patents and R\&D expenditures. Patents are generally viewed as having three weaknesses: 1) they measure inventions rather than innovations; 2) the tendency to patent varies across countries, industries and processes; and 3) firms often protect their innovations by using methods other than patents (maintaining technological complexity, industrial secrecy, and lead time over competitors). Using R\&D expenditures may also be inappropriate because not all innovations are generated by R\&D expenditures, R\&D does not necessarily lead to innovation (it is an input rather than output), and formal R\&D measures are biased against small firms (see e.g. Michie (1998), Archibugi and Sirilli (2001)). More importantly for this paper, patenting and formal R\&D are less likely to be observed in emerging market economies. Domestically owned firms are expected to engage more in imitation and adaptation of already created and tested technologies, rather than generating new inventions or expending resources on R\&D. This is substantiated in our data where the majority (70\%) of firms who

\footnotetext{
${ }^{13}$ In another validity check of self-reported measures, we find that self-reported measures of financial constraints are strongly positively correlated with the probability to be denied a loan and the interest rate on received loans.
} 
answered that they acquired a new technology said that it was embodied in new machinery or equipment that was purchased or licensed from other sources. Furthermore, the measures we use capture management innovations, which can be argued to be more important than inventions for improving a firm's competitiveness and efficiency. Overall, our measures of innovation are in agreement with the recommendations of the Oslo Manual (OECD (2005)) suggesting the use of survey measures of innovations which are "new to the firm".

To complement our analysis of innovation, we also consider two additional measures of innovation. First, we construct a dummy variable equal to one if a firm reports positive R\&D spending and zero otherwise. We prefer using this measure of innovation to the volume of R\&D spending because the distribution of $R \& D$ spending is highly skewed with a large mass of firms reporting zero R\&D expenditures. Unfortunately, few firms answer the question about R\&D spending so that the sample size with non-missing responses shrinks by approximately $50 \%$.

Second, we construct a measure of total factor productivity (TFP) which captures the derived effect of innovations. We compute TFP using the cost shares for labor, material and capital (computed for each firm and aggregated for a given industry in each country and year) and adjust it for capacity utilization $(C U)$ :

$$
\log T F P_{i s c t}=\log Y_{i s c t}-s_{s c}^{L} \log L_{i s c t}-s_{s c}^{M} \log M_{i s c t}-s_{s c}^{K} \log K_{i s c t}-\log C U_{i s c t}
$$

where $i, s, c$, and $t$ index firms, industries, countries and time, $s_{s c}^{L}, s_{s c}^{M}, s_{s c}^{K}$ are labor, materials and capital cost shares, $Y$ is sales, $L$ is number of employees, $M$ is the value of materials and $K$ is the replacement value of capital. ${ }^{14}$ Since only about one-half of the firms report sales revenue and even fewer report capital, the TFP-measure is available for less than 5,000 firms.

Because we lose so many observations with the R\&D dummy and TFP-based measure of innovation, we use these alternative measures only as a robustness/validity check. For example, we show in Table 1 that self-reported measures of innovation are indeed positively related to objectively measured productivity and thus they are meaningful indicators of productivity enhancing activities. Furthermore, the intensity of innovation and exporting activities reported in BEEPS is strongly positively correlated with the growth rate of real GDP per capita (Figure 3). Hence, New Product and New Technology are meaningful indicators of innovation and our analysis can provide micro-foundations for interpreting the correlation between financial and economic development at the macroeconomic level as a causal one.

\footnotetext{
${ }^{14}$ The interpretation of the measured productivity given by equation (14) should be careful. As argued by Gorodnichenko (2007) and others, measured productivity captures the revenue generating ability of firms (which includes both market power and technology level) rather than the technology level of firms.
} 


\section{Econometric Specification}

We estimate the following baseline probit specification with the pooled data in the 2002 and 2005 BEEPS for private domestically owned firms (i.e., with no foreign or state ownership):

$$
\begin{aligned}
I_{i s c t}=\Phi\left\{\alpha_{0} F C_{i s c t}\right. & +\beta_{1} \log L_{i s c, t-3}+\beta_{2}\left(\log L_{i s c, t-3}\right)^{2}+\beta_{3} E d u_{i s c, t-3} \\
& +\beta_{4} S k i l l_{i s c, t-3}+\beta_{5} A_{g e_{i s c t}}+\beta_{6} C M N_{i s c t}+\beta_{7} M_{\text {arkup }} \text { isct }_{\text {ist }} \\
& +\beta_{8} S M N E_{i s c t}+\beta_{9} \text { Import }_{i s c t}+\beta_{10} C U_{i s c, t-3} \\
& \left.+\gamma L o c_{i s c t}+\lambda_{s}+\eta_{c}+\psi_{t}+\text { error }\right\}
\end{aligned}
$$

where $I$ is a dummy variable equal to one if the firm reported a productivity enhancing activity (i.e., innovation or export), and zero otherwise; $\Phi$ denotes c.d.f. of a standard normal random variable; $i, s, c$, and $t$ index firms, industry, country, and time, respectively. For continuous measures of innovation such as TFP we estimate the linear analogue of specification (15) with the same set of regressors. Variables dated with period are taken from retrospective questions about the firm's performance three years prior to the current date. In addition to industry $\left(\lambda_{s}\right)$, country $\left(\eta_{c}\right)$ and year $\left(\psi_{t}\right)$ fixed effects, the following variables are included to control for a number of firm-specific factors deemed to be important in the literature:

$F C$, the main variable of our analysis, is a measure of financial constraints faced by firms. Our theory predicts that $\alpha_{0}$ should be negative. To measure FC we will employ two variables, Difficulty of Access to External Finance and Cost of External Finance.

$L$ (the number of employees) measures the size of the firm. The argument for including size is that large companies have more resources to innovate and can benefit from economies of scale in R\&D production and marketing.

$E D U$ (the share of workers with a university education) and SKILL (the share of skilled workers) capture human capital in the firm. These variables might be expected to be positively correlated with innovation if $E D U$ reflects the involvement of workers in $\mathrm{R} \& \mathrm{D}$ and more skilled workers $(S K I L L)$ are able to give feedback to the firm on how to improve a product.

Age of the firm is the log of the number of years since the firm began operations in the country. Two hypotheses are plausible: one suggesting that older firms developed routines that are resistant to innovation and another suggesting that older firms will accumulate the knowledge necessary to innovate. There is evidence for both hypotheses.

Variables $C N M$ and Markup capture competitive pressures. $C N M$ is a dummy equal to one if the firm competes in the national markets and zero otherwise (e.g., when a firm only 
competes in a regional or local market). We expect $C N M$ to have a positive effect on innovation, given that the firm operates in a larger market. Markup (the price to cost ratio) is used as a proxy to estimate the effect of competition faced by each firm (see e.g., Nickell (1996); Aghion et al. (2005)). Gorodnichenko et al. (2009) show that both Markup and $C N M$ are positively related to the incidence of innovations.

$S M N E$ (the share of sales to multinational enterprises) and Import (the share of imported inputs) capture vertical linkages or transfer of capabilities. Presumably exposure to foreign firms and markets is likely to stimulate more innovation as foreign firms and markets are likely to have better technologies, practices and products.

Location $(L O C)$ is a set of dummies for size of population where the firm is operating or headquartered. This will control for potential differences in knowledge available in larger v. smaller cities.

Capacity Utilization $(C U)$ is the percentage of a firm's output relative to maximum possible output. Although capacity utilization has been found to be a strong predictor of innovations (e.g. Becheikh et al. (2006)), the effect of $C U$ on innovation is a priori indeterminate. If firms are too busy filling demand, they may be more interested in extending their current capacity than finding new ways of producing goods and services. At the same time, if firms are at capacity they may need to innovate.

Appendix Tables A1-A2 provide summary statistics for variables used in our analyses.

Estimating specification (15) by ordinary least squares or probit may lead to biased estimates of the key parameter $\alpha_{0}$. For example, Canepa and Stoneman (2008) report that firms from high tech industries and small firms in the U.K. are more likely to report a project being abandoned or delayed due to financial constraints. In other words, consistent with our model, firms that intend to innovate are more likely to hit a financial constraint than firms that do not even try. Hajivassiliou and Savignac (2007) make a similar observation based on French survey data. They illustrate the issue by estimating the sensitivity of innovation to financial constraints for two samples of firms: the full sample, which includes all firms, and a restricted sample. In the restricted sample, they include firms that are likely innovators and exclude firms that show no innovation activity despite being not financially constrained. Hajivassiliou and Savignac (2007) find that innovation and financial constraints are positively correlated in the full sample and negatively in the restricted sample. In summary, innovating firms are more likely to hit financial constraints and therefore one may find a positive relationship between financial constraints and incidence of successful innovations.

To correct for this endogeneity bias, we propose using instrumental variables which affect financial constraints but do not (directly) influence the intensity of innovative/exporting activities. Exogenous shocks to cash receipts of a firm appear to be a natural candidate since they can 
be interpreted as $\delta_{L}$ in our model. Such shocks affect the amount of internal funds as well as attractiveness of firms to external creditors but do not influence innovations directly.

Fortunately, BEEPS collects information about the structure of revenues as well as timeliness of payments from customers and to suppliers. We focus on variables which are most likely to be observed by external creditors and thus are likely to influence access to external finance. Specifically, we will use three variables. The first variable Overdue is the dummy variable equal to one if a firm has overdue payments to suppliers. Presumably, overdue payments to suppliers strongly signal that a firm experiences a financial difficulty. Since external creditors may be unable (e.g., due to asymmetric information) to differentiate insolvent vs. illiquid (but solvent) firms, availability of external financing is likely to fall for firms with overdue payments. ${ }^{15}$ The second variable NTPcustomer is the share of payments from customers settled by debt swaps or offsets and exchange of goods for goods (barter). The third variable NTPsupplier is the share of payments to suppliers settled by debt swaps or offsets and exchange of goods for goods (barter). Since debt swaps and barter are less likely to provide liquidity, firms engaged in these types of payment settlements are more likely to experience financial constraints. ${ }^{16}$ We also consider alternative instrumental variables (e.g. whether firms took non-paying customers to court) in the robustness checks. $^{17}$

\section{$5 \quad$ Analysis of productivity enhancing activities}

\subsection{Productivity gap}

We begin our empirical analysis by documenting that foreign owned firms are more productive than domestically owned firms in BEEPS. Table 2 shows that domestically owned firms are 10 to 20 percent less productive than companies under foreign ownership and that this productivity gap appears to widen over time, which is consistent with previous studies (see e.g. Sabirianova Peter et al. (2005)). Likewise we observe that foreign owned firms innovate more intensively than domestically owned firms. We also find that the gap is not eliminated after we control for the initial level of firm's total factor productivity.

\footnotetext{
${ }^{15}$ One potential concern one might have about Overdue as an instrument may be that it may itself not be truly exogenous but arise from liquidity shocks due to low demand for the firm's products or low productivity. We will show below that controlling for capacity utilization and productivity does not invalidate the power of our instruments.

${ }^{16}$ As Marin and Schnitzer (2002) and Marin and Schnitzer (2005) show for transition economies, firms resort to barter if they are considered not creditworthy. But there is an additional mechanism which can make these types of payments exacerbate financial constraints. As discussed in Gorodnichenko and Grygorenko (2008), debt swaps or offsets and exchange of goods for goods were often employed by management to channel resources away from stakeholders. Since external creditors are particularly vulnerable to these types of looting, they may be more reluctant to provide credit to firms that engage in these forms of settling payments to suppliers and payments from customers.

${ }^{17}$ An additional source of discrepancy between regular and IV probits could be measurement errors in self-reported measures of financial constraints. Using instrumental variables could correct the attenuation bias as well.
} 
Although our data do not permit us to properly control for possible selection of productive firms into foreign ownership ("cherry picking"), we can check the quantitative importance of such effects by assessing the gap for de novo firms which were founded after 1991 and were never in state ownership. Importantly, in contrast to privatized firms, de novo private firms were unlikely to be purchased by foreign owners until recently (Meyer (2002)). Thus, we effectively compare "greenfield" domestically and foreign owned firms. Our results are very similar to the results we obtain for the baseline sample and hence the selection effects should not distort our results to any significant extent. ${ }^{18}$

The large and persistent gap in measured productivity and innovation/export intensity is hard to reconcile with extensive reforms taken by BEEPS countries to accelerate growth and catching up with the technological frontier. As we conjecture above, a part of the gap could be explained by differential access of foreign and domestically owned firms to external credit. Indeed, Table 3 documents that foreign firms report milder financial frictions (e.g. because they can more often borrow in internal markets (e.g. from a mother company)) than private domestically owned companies. In the rest of the section, we investigate how productivity enhancing activities of domestically owned firms are affected by financial constraints.

\subsection{Main findings}

In this section, we present estimates of equation (15), which tests the main hypotheses described in Section 2. Our baseline specification for each measure of innovation is reported in Table 4 . In addition to estimated coefficients and standard errors, we also report the elasticity of innovation with respect to financial constraints: $(\partial I / \partial F C)(\overline{F C} / \bar{I})$ where $(\partial I / \partial F C)$ is the marginal effect of financial constraint $F C$ on a measure of innovation $I$ (evaluated at mean values), and $\overline{F C}$ and $\bar{I}$ are mean values of reported severity of financial constraint and reported innovation respectively. The advantage of using elasticity is that it makes the sensitivity of innovation to financial constraints comparable across regressions since mean innovation rates vary across samples and definitions. Our baseline sample includes only private domestically owned firms.

For all measures of innovation, we consistently find that a binding financial constraint is strongly negatively related to the incidence of innovations, as predicted by Hypothesis 1, according to instrumental variable estimates. At the same time, in the regular probit, we do not find any

\footnotetext{
${ }^{18}$ This finding is consistent with Estrin et al. (2009) documenting that the productivity gap between domestically and foreign owned firms does not shrink considerably after controlling for selection into foreign ownership. It is possible that foreign owned firms reported more intensive innovations because they can "import" new technologies and goods from parent companies. Although it is true that foreign owned companies report greater incidence of transfers of new technologies from parent companies, the frequency of such transfers is quite modest. In the 2005 wave of BEEPS when the relevant data were collected, less than ten percent of foreign owned firms that reported developing or acquiring a new technology indicated that the technology was transferred from parent companies. Thus a vast majority of innovations of foreign owned firms is likely to be produced locally and hence the comparison with domestically owned firms is meaningful.
} 
significant relationship between innovations and access to external finance. ${ }^{19}$ As explained in Section 4, the endogeneity of innovation and financial constraints will bias least squares estimates upward since more innovative firms are more likely to need external funding and hence more likely to hit financial constraints. This result is in line with the previous research (e.g., de Mel et al. (2008), Banerjee and Duflo (2008)) documenting that least squares estimates are biased towards small treatment effects of financial constraints and instrumental variable estimates are much larger than least squares estimates. However, this pattern contrasts with results in Ayyagari et al. (2007) who find very similar least squares and instrumental variable estimates.

Once the endogeneity bias is corrected, we find a strong negative causal effect of financial constraints on innovation. Specifically, the bottom panel of Table 4 shows that the elasticity of innovations with respect to financial constraints implied by estimates in the top panel of Table 4 is in -1.5 to -1 range for developing a new good or adopting a new technology, approximately -2 for the R\&D spending, and -0.5 for TFP. These are economically significant magnitudes. For example, a one-standard deviation increase in the severity of financial constraints lowers the probability of a successful innovation by 18 percentage points for developing a new good, 24 percentage points for adopting a new technology, 28 percentage points for positive R\&D spending, and 25 percentage points for TFP.

Note that our instrumental variables have desirable properties such as being strong predictors of the endogenous variable (the F-statistics for the first stage fit is well above 10, a value commonly suggested as a sign of variables to be good instruments) and orthogonality to the error term (the pvalue of the over-identifying restriction test is routinely above any standard significance level). We report first stage estimates in Appendix Table A3. Consistent with predictions of economic theory, positive Overdue, NTPcustomer and NTPsupplier raise the severity of financial constraints. However, Overdue appears to be the strongest predictor of financial constraints. ${ }^{20}$

There are a number of interesting findings with respect to the control variables in Table 4. First, larger firms are more to likely to report innovations than smaller firms, which is consistent with the finding in the vast majority of studies on innovation (see e.g., Becheikh et al. (2006)) and the Schumpeter (1943) hypothesis. The size effect is concave for both types of innovations. Second, the effect of human capital varies by how it is measured. Having a higher share of skilled workers does not affect the probability of developing a new product and acquiring new technology. On the other hand, as the share of workers with a university education rises, all types of innovation are boosted. These findings stress the need for a highly educated labor force to improve the capabilities of the product or service. Third, older (more mature) firms are not as likely to innovate with respect to product and technology as new firms. Fourth, firms that compete/operate in national markets are

\footnotetext{
${ }^{19}$ We find similar results for linear probability models.

${ }^{20}$ Interestingly, after conditioning on industry/country dummies, observable characteristics of firms other than those related to liquidity and capacity utilization (and as we discuss later initial levels of debt and productivity) are not strong predictors of reported financial constraints. Capacity utilization has the expected sign, i.e. the larger demand, as captured by higher capacity utilization, the less fnancially constrained does the firm feel.
} 
more likely to innovate in any of the three areas than firms that only compete/operate in a local or regional market. This may reflect both the capability of the firms operating in the larger national market, as well as the characteristics of the national as opposed to local environment. Fifth, lower competition, proxied by markup, has a positive effect on innovation, which is consistent with the results in Carlin et al. (2006) and Gorodnichenko et al. (2009) who use a similar econometric framework. Sixth, consistent with Gorodnichenko et al. (2009), linkages to foreign firms (SMNE and Import) are positively associated with the success of innovation. Finally, more intensive capacity utilization is associated with less intensive innovative activities.

Table 5 reports the estimates for specification (15) where we replace the innovation dummy with an export dummy. We consider two measures of export status. The first is the dummy variable (Export) equal to one if a firm exports any of its goods directly or indirectly and zero otherwise. The second is the dummy variable (NewExport) equal to one if a firm has started to export in the last 3 years and zero otherwise. Consistent with the fact that starting new export involves larger expenses than maintaining export status (e.g. Das et al. (2007)), we find that NewExport is more sensitive to financial constraints than Export. Again, the effects of financial constraints are economically and statistically significant. Thus, strengthening previous findings, we confirm that exporting is affected by financial constraints.

\subsection{Analysis of subsamples}

To investigate possible heterogeneity of causal effects of financial constraints on innovation across types of firms, we re-estimate specification (15) for a series of subsamples. In these subsamples, we focus only on the incidence of acquiring new technology and developing a new good as well as export status. For two other measures of innovation (TFP and positive R\&D spending) and for NewExport, we have too few observations for certain cells which makes statistical analysis imprecise and sensitive to a handful of observations. Table 6 reports our results for various subsamples which differentiate firms by sector, age, size, ownership, region and time period.

First, by and large the strength of the causal effect is somewhat larger for services than for manufacturing, although in many cases we cannot reject the null of equality for these two sectors. The stronger responses for services probably reflect the fact that it is easier for firms in the manufacturing sector to collateralize (e.g., pledge a new piece of equipment as collateral for a loan) borrowing from external creditors than for firms in the service sector which tends to be more intensive in labor and possibly intangible assets such as loyalty of customers and customer base. According to this interpretation, the stronger response of the service sector to financial constraints may reflect higher cost of external finance due to lower collateralization, as suggested by Hypothesis 2 .

Second, we also find that new firms are more sensitive to financial constraints than old firms. This finding is consistent with the idea that new firms may have shorter credit history which 
makes access to external financing harder and that they have had less opportunities to accumulate internal funds and hence need to rely more on external finance. Our finding is consistent with previous studies reporting that R\&D spending of mature firms is much less sensitive to cash flow and external equity than that of young firms (e.g., Brown et al. (2009)).

Third, the strength of the response strongly varies with the firm size. Small firms (2 to 10 employees) have the elasticity of innovation with respect to financial constraints two to three times larger than the elasticity of large firms (100 and more employees). This result is consistent with many previous studies documenting that small firms are more likely to experience lack of external funds and severe informational frictions than large firms (see e.g. Harhoff (1998), Canepa and Stoneman (2008) and Ughetto (2008)).

Fourth, the sensitivity can also vary with the level of development of financial markets. Generally, more developed financial markets are more likely to overcome asymmetric information and other impediments for access to external credit. To examine this hypothesis, we split countries into four regions commonly used in the analysis of Eastern European and CIS countries: Central European and Baltic countries which became new EU members; South-East European (SEE) countries (mainly Balkans); Western CIS (WCIS) countries (Belarus, Russia, Ukraine); Eastern CIS (ECIS) countries (Caucasus and Central Asia). The ranking of financial market development as an indicator of accessability of external finance typically runs from new EU members (most developed) to SEE to WCIS to ECIS (least developed). Therefore, according to Hypothesis 2, we should expect that the sensitivity to financial constraints should be the lowest in new EU member countries and the highest in the Eastern CIS countries. Our results strongly support this prediction. We find a relatively monotonous increase in sensitivity as we move from more to less financially developed economies. ${ }^{21}$

Fifth, we re-estimate specification (15) for state owned and foreign owned firms. Both types of firms are less likely to experience financial constraints since they can borrow funds internally either from an appropriate level of government (directly or indirectly using loan guarantees from the government) or from a mother company. Thus, they are less likely to be forced to rely on costly external finance, even in case of negative liquidity shocks, and hence we should expect a weaker (if any) effect of financial constraints on innovation. ${ }^{22}$ This conjecture is by and large supported by our results: only state owned firms exhibit some sensitivity to financial constraints; in all other cases, we find no significant sensitivity. Thus, we can identify financial constraints as one important reason for why domestically owned firms innovate/export less than foreign firms do, why domestically owned firms are less productive than foreign firms and why they do not catch up over time.

\footnotetext{
${ }^{21}$ Our ranking of the countries is also consistent with the ranking of venture capital deals across countries, as documented by e.g. VentureXpert. Specifically, new EU member countries have the largest number of venture capital deals while ECIS countries have the lowest.

${ }^{22}$ For example, Harrison and Mcmillan (2003) report for firms in Côte d'Ivoire that domestically owned firms are more credit constrained in their investment than foreign firms.
} 
Finally, we explore the sensitivity of our results to different time samples and we find similar results for 2002 and 2005 waves of BEEPS.

\subsection{Robustness checks}

Financial constraints have many dimensions. Typically, financial constraints are measured along (i) whether firms have access to external credit and (ii) the price firms have to pay for external credit if they have access to it. We have focused on whether firms have access to credit. In Table 7, we examine if our results also extend to the price of credit which we measure with the cost of external credit variable. This variable is a self-reported measure of the cost of financing which runs on 1 ("No obstacle") to 4 ("Major obstacle") scale. We find that results are largely the same as for the access to credit and thus we do not report all sample splits to preserve space.

To check for possible selection effects into foreign ownership, we explore the sensitivity of estimates to restricting the sample only to de novo firms and again find similar results. Likewise our results do not change substantively when we recode the ordinal self-reported measure of financial constraints into dummy variables equal to one if firms indicate severe constraints and zero otherwise (results are not reported).

In another robustness check, we examine if additional instrumental variables affect our estimate of innovation sensitivity to financial constraints. Specifically, we use a dummy variable which is equal to one if a firm had to resolve non-payment from customers in court. As shown in Table 7, we find results similar to our baseline.

We also experiment with qualitatively different instrumental variables. Specifically, we can examine how our estimates change when we use EBRD's indices of reforms in banking and financial sectors. These reforms are likely to improve access to external credit and lower its cost. Indeed, Figure 4 shows that the self-reported measures of financial constraints are strongly negatively correlated with the EBRD's indices of reforms in the financial and banking sectors. Note that unlike instrumental variables used in previous research (e.g. legal origin), these indices are time varying and hence we can exploit within-country variation which may be a more credible source of identification. Overall, estimates based on this alternative set of instrumental variables are remarkably similar to our baseline estimates. ${ }^{23}$

Our theory predicts that innovations are increasingly sensitive in their ability to be collateralized, as higher collateralization lowers the cost of external finance. To test this prediction, we use information (contained in the 2005 wave of BEEPS) about how new technology was implemented. Specifically, we construct two measures of new technology: i) machine-based when firms report that their new technology was mainly embodied in new equipment; ii) non-machine-based when new technology was primarily a result of research efforts. Consistent with our theory, we find that

\footnotetext{
${ }^{23}$ Although the strength of the first stage fit with these alternative instruments is sufficiently strong (F-statistic is in the range between 12 and 15), the firm-level instrumental variables clearly dominate country-level instruments in terms of first-stage predictive power for variables measuring financial constraints.
} 
non-machine-based new technology is more sensitive to financial constraints than machine-based acquisition of new technology. ${ }^{24}$

It is possible that our results might be driven by omitted variables (e.g. level of productivity, managerial ability, initial conditions) correlated with innovation/export, financial constraints and our instrumental variables. ${ }^{25}$ Note that capacity utilization partially addresses these concerns because, as argued in Abel and Eberly (1998), capacity utilization may serve as a sufficient statistic for the state of demand and technology conditions. To further explore the sensitivity of our estimates to these potentially omitted factors, we estimate a series of specifications augmented with variables proxying for these omitted factors. In particular, the augmented regressions include the level of labor productivity and level of debt as a fraction of total assets three years before the current year in the survey wave, ${ }^{26}$ level of education of the general manager, ${ }^{27}$ index of limiting factors, ${ }^{28}$ a dummy variable for a firm being defendant in courts. With these additional controls, we find estimates of the causal effect of financial constraints on innovation and export status similar to our baseline set of estimates and therefore these omitted factors are not likely to strongly bias our estimates.

\subsection{Interaction of export and innovation}

Previous research documents that financial constraints affect the export status of firms (Berman and Héricourt (2008), Buch et al. (2009), Bellone et al. (2008), Greenaway et al. (2007)). It is also firmly established that exporting firms are more productive and innovate more than nonexporting firms (Aw and Hwang (1995), Bernard and Jensen (1995), Bernard and Jensen (2004)), Bernard and Wagner (1997); see Wagner (2007) for a survey). However, the interplay between how exporting firms acquire these advantages over non-exporters is less clear. Importantly, causation may flow from export status to productivity (Grossman and Helpman (1991), World Bank (1991),

\footnotetext{
${ }^{24}$ We also experimented with including firm fixed effects to control for time-invariant factors. Although the signs of the estimated coefficients in fixed effect regressions were in line with the estimates we report for specifications without firm fixed effects, the sample size in fixed effect regressions was too small (about 700 firms) to have precise estimates given the amount of heterogeneity we have in the data. These results are available upon request.

${ }^{25} \mathrm{It}$ is not possible to a priori sign the bias stemming from these potentially omitted factors. On the one hand, these factors are likely to be negatively correlated with the instruments, financial constraints and positively with the innovation so that IV overstates the treatment effect of financial constraints. On the other hand, these factors are likely to push firms into more innovation and hence these firms are more likely to hit financial constraints so that IV understates the treatment effect of financial constraints.

${ }^{26}$ This information is taken from retrospective questions. In this exercise we prefer labor productivity to total factor productivity because with labor productivity we have more observations than with total factor productivity. Results are similar when we use total factor productivity although the precision of TFP-based estimates is smaller. Information on the level of debt was collected only in the 2002 wave of BEEPS. We do not include these additional regressors in the baseline specification because these variables have many missing values which would substantially reduce the sample size available for estimation.

${ }^{27}$ This information was collected only in the BEEPS 2002 wave.

${ }^{28}$ The index of limiting factors is computed as the average score - running from 1 ("No obstacle") to 4 ("Major obstacle") - of how problematic different factors (access to infrastructure, regulation burden, crime, property rights, etc) are.
} 
World Bank (1993), Van Biesebroeck (2005), and De Loecker (2007) for theoretical arguments and empirical evidence). In this section, we try to tie together effects of financial constraints on export status and innovation.

Our theoretical model suggests that measured productivity, export status and innovation are jointly determined. Furthermore, export status and innovation depend on the severity of financial constraints. Specifically, for mild financial constraints, it is always optimal for firms to engage in both exporting and innovation since both activities are complementary. However, for sufficiently binding financial constraints, the activities become substitutes. Intuitively, both activities must rely on internal financing since neither activity can be collateralized. With mild financial constraints, both activities can be funded with internal or, if need be, external resources and since one activity reinforces the other it is optimal for firms to do both activities. With a binding financial constraint, only one activity can be funded and, hence, export and innovation become substitutes. In what follows, we examine formally this testable implication (Hypothesis 3) of our theoretical model.

To study the interplay between export and innovation, we construct two additional variables. The first variable $(E \& I)$ is the dummy variable equal to one if a firm both exports and innovates. The second variable (Eor $I)$ is the dummy variable equal to one if a firm either exports or innovates but does not do both activities. E\&I captures the complementary nature of export and innovation. Eor I reflects the substitutable nature of export and innovation. As we discussed above, the incidence of E\&I relative to EorI should be a decreasing function in the severity of financial constraints. This means, in practice, that if we use specification (15) with E\&I and EorI as the dependent variables, the elasticity of $E \& I$ with respect to financial constraint should be greater than the elasticity of EorI with respect to financial constraint. We look for this pattern by estimating the E\&I and Eor I regressions separately (i.e. IV probit for each regression) and as a multinomial IV probit. The advantage of the latter approach is that we can explicitly take into account the correlation across outcomes. We find (Table 8) that the elasticity for E\&I is statistically and economically significantly larger in the E\&I regression than it is for Eor $I$ in the Eor I regression, thus confirming Hypothesis 3.

This finding clearly indicates that firms may be forced to a suboptimal behavior when financial frictions are severe. In particular, firms may fail to fully materialize gains from complementary export and innovation activities. Inability to jointly innovate and export can considerably slow down technological catching up to the frontier and thus can lead to persistent gaps between domestically and foreign owned firms.

\section{Reconciling the facts and policy implications}

We started our analysis with the stylized fact that in developing and transition economies, foreign owned firms are more productive than domestically owned firms and that this productivity gap 
is not decreasing over time. The evidence from BEEPS is consistent with this observation. As documented in Section 5.1, domestically owned firms in our sample are significantly and robustly less productive than companies under foreign ownership and foreign owned firms innovate more intensively than domestically owned firms. In other words, domestically owned firms fall behind the technological frontier often represented by foreign owned firms.

We conjectured that this gap in productivity and innovation may be due to more several financial constraints faced by domestically owned firms. Our findings support this conjecture: domestically owned firms are strongly hampered in their innovation and export activities by difficult and costly access to external finance. Furthermore, because of financial frictions, domestically owned firms cannot exploit potential complementarities between innovation and export activities which further widens the productivity gap. Thus, our results provide micro-foundations for a causal interpretation of the positive correlation between development of financial markets and the level of income at the macroeconomic level.

As underdevelopment of financial and banking sectors is particulary acute in developing and transition economics, design and evaluation of reforms to reduce the adverse effects of financial frictions and to spur productivity acceleration is an area of active and current policy debates. Our results provide several implications for these discussions. First of all, evidence presented in this paper may help to understand why the productivity of domestically owned firms in emerging economies catches up slowly to the technological frontier. Specifically, we argue that domestically owned firms may find it difficult to finance their productivity enhancing activities. We also offer a more detailed perspective for policymakers. We document that financial frictions are particularly detrimental for small or young firms. Policies aimed to help these types of firms are likely to have the biggest effect. We also find that firms in the service sector are more sensitive to financial constraints probably because it is harder to collateralize investment and innovation in this sector. Since the service sector has been underdeveloped in emerging market economies and, consequently, there is a grave need to expand the size and quality of the service sector, public policy should provide support to firms in the service sector so that they can overcome financial frictions and catch up faster to world standards. For instance, transition and emerging market economies can benefit from emulating policies that support innovations of firms most sensitive to financial frictions (e.g., Small Business Innovation Research grants in the U.S.A.).

More broadly, our cross-country analysis of firms' behavior at the micro level strongly indicates that the severity of financial frictions faced by firms is decreasing in the level of development of financial markets. Since financial frictions slow down improvements in technology and the welfare costs of delayed productivity catch up are probably enormous, policy should also be directed toward establishing a framework for deep credit markets and a strong banking sector willing to provide access to external financing for a broad range of firms. To be clear, we do not advocate "sprinkling" money (i.e. blind injection of liquidity into firms), which neglects the disciplinary effects of external 
finance that comes from careful screening and monitoring. Instead, a sensible strategy may include enhanced screening process, improved information systems, and well maintained clear property records. Deeper reforms in banking and financial sectors are likely to alleviate the adverse effects of financial frictions (recall Figure 4) and, consequently, to stimulate the growth of the economies in our sample.

Our findings also suggest that financial constraints may force firms to choose between innovation and internationalization strategies, thus losing out on the complementary effects of both strategies. This could explain why domestically owned firms in emerging economies benefit less from trade liberalization than should be expected a priori. The problem may be that they lack the finance to take advantage of new export opportunities, while being confronted with increased import competition. Thus, the integration of international product markets does not have the desired effects of pushing domestically owned firms towards the technology frontier if it is not accompanied by complementary financial market reforms.

Foreign multinationals may ease local credit constraints by bringing foreign capital into the economy which is consistent with the negative correlation between foreign presence and selfreported financial constraints. However, to the extent that foreign firms borrow locally, they can also crowd out domestic borrowers and exacerbate financial constraints faced by domestically owned firms (see Marin and Schnitzer (2006) and Harrison and Mcmillan (2003) for further discussion and evidence). Deeper understanding of globalization trade-offs as well as establishing exact mechanisms of how foreign presence affects financial frictions in developing economies is an important task for future studies.

\section{References}

Abel, A. B. and Eberly, J. C. (1998), 'The mix and scale of factors with irreversibility and fixed costs of investment', Carnegie-Rochester Conference Series on Public Policy 48(1), 101-135.

Aghion, P., Bloom, N., Blundell, R., Griffith, R. and Howitt, P. (2005), 'Competition and innovation: An inverted-U relationship', Quarterly Journal of Economics 120(2), 701-728.

Aitken, B. J. and Harrison, A. E. (1999), 'Do domestic firms benefit from direct foreign investment? Evidence from Venezuela', American Economic Review 89(3), 605-618.

Archibugi, D. and Sirilli, G. (2001), The direct measurement of technological innovation in business. in "Innovation and enterprise creation: Statistics and indicators. Proceedings of the conference held at Sophia Antipolis".

Arnold, J. M. and Javorcik, B. S. (2009), 'Gifted kids or pushy parents? Foreign direct investment and plant productivity in Indonesia?', Journal of International Economics 79(1), 42-53.

Atkeson, A. and Burstein, A. (2007), Innovation, firm dynamics, and international trade. NBER Working Paper No. 13326.

Aw, B. and Hwang, A. R. (1995), 'Productivity and the export market: A firm-level analysis', Journal of Development Economics 47(2), 313-332. 
Ayyagari, M., Demirgüç-Kunt, A. and Maksimovic, V. (2007), Firm innovation in emerging markets: The roles of governance and finance. World Bank Policy Research Working Paper 4157.

Banerjee, A. V. and Duflo, E. (2005), Growth theory through the lens of development economics, in P. Aghion and S. Durlauf, eds, 'Handbook of Economic Growth', Vol. 1 of Handbook of Economic Growth, Elsevier, chapter 7, pp. 473-552.

Banerjee, A. V. and Duflo, E. (2008), 'Do firms want to borrow more? Testing credit constraints using a directed lending program', mimeo .

Becheikh, N., Landry, R. and Amara, N. (2006), 'Lessons from innovation empirical studies in the manufacturing sector: A systematic review of the literature from 1993-2003', Technovation 26(5-6), 644-664.

Bellone, F., Musso, P., Nesta, L. and Schiavo, S. (2008), Financial constraints and firm export behavior. Department of Economics (University of Trento) Working Paper 0816.

Berman, N. and Héricourt, J. (2008), Financial factors and the margins of trade: Evidence from cross-country firm-level data. Documents de travail du centre d'Economie de la Sorbonne bla08050.

Bernard, A. B. and Jensen, B. J. (1999), 'Exceptional exporter performance: Cause, effect, or both?', Journal of International Economics 47(1), 1-25.

Bernard, A. B. and Jensen, J. B. (1995), 'Exporters, jobs and wages in U.S. manufacturing: 19761987', Brookings Papers on Economic Activity: Microeconomics pp. 67-119.

Bernard, A. B. and Jensen, J. B. (2004), 'Why some firms export', The Review of Economics and Statistics 86(2), 561-569.

Bernard, A. B. and Wagner, J. (1997), 'Exports and success in German manufacturing', Review of World Economics (Weltwirtschaftliches Archiv) 133(1), 134-157.

Blomstrom, M. (1988), 'Labor productivity differences between foreign and domestic firms in mexico', World Development 16(11), 12951298.

Bond, S., Harhoff, D. and Van Reenen, J. (2006), 'Investment, R\&D and financial constraints in Britain and Germany', Annales d'Economie et de Statistique 79-80, 1-28.

Brown, J. R., Fazzari, S. M. and Petersen, B. C. (2009), 'Financing innovation and growth: Cash flow, external equity, and the 1990s R\&D boom', Journal of Finance 64(1), 151-185.

Buch, C. M., Kesternich, I., Lipponer, A. and Schnitzer, M. (2009), Exports versus FDI revisited: Does finance matter? Unpublished manuscript.

Bustos, P. (2007), Rising wage inequality in the argentinean manufacturing sector: The impact of trade and foreign direct investment on technology and skill upgrading. Unpublished manuscript.

Canepa, A. and Stoneman, P. (2008), 'Financial constraints to innovation in the UK: Evidence from CIS2 and CIS3', Oxford Economic Papers 60, 711-730.

Carlin, W., Schaffer, M. and Seabright, P. (2006), 'A minimum of rivalry: Evidence from transition economies on the importance of competition for innovation and growth', Contributions to Economic Analysis and Policy 3(1), 1-30.

Chaney, T. (2005), Liquidity constrained exporters. University of Chicago, Unpublished manuscript. 
Constantini, J. A. and Melitz, M. J. (2008), The dynamics of firm-level adjustment to trade liberalization, in E. Helpman, D. Marin and T. Verdier, eds, 'The Organization of Firms in a Global Economy', Harvard University Press, Cambridge, chapter 4.

Das, S., Roberts, M. and Tybout, J. (2007), 'Market entry costs, producer heterogeneity, and export dyanmics', Econometrica 75(3), 837-873.

De Loecker, J. (2007), 'Do exports generate higher productivity? Evidence from Slovenia', Journal of International Economics 73(1), 69-98.

de Mel, S., McKenzie, D. and Woodruff, C. (2008), 'Returns to capital in microenterprises: Evidence from a field experiment', mimeo .

Estrin, S., Hanousek, J., Kocenda, E. and Svejnar, J. (2009), 'The effects of privatization and ownership in transition economies', Journal of Economic Literature 47(3), 699 - 728.

Gorodnichenko, Y. (2007), Using firm optimization to evaluate and estimate returns to scale. NBER Working Paper 13666.

Gorodnichenko, Y. and Grygorenko, Y. (2008), 'Are oligarchs productive? Theory and evidence', Journal of Comparative Economics 36(1)(1), 17-42.

Gorodnichenko, Y., Svejnar, J. and Terrell, K. (2009), 'Globalization and innovation in emerging markets', American Economic Journal: Macroeconomics .

Greenaway, D., Guariglia, A. and Kneller, R. (2007), 'Financial factors and exporting decisions', Journal of International Economics 73(2), 377-395.

Grossman, G. and Helpman, E. (1991), 'Innovation and growth in the global economy', Cambridge Massachusetts: MIT Press .

Haddad, M. and Harrison, A. E. (1993), 'Are the positive spillovers from direct foreign investment? Evidence from panel data for Morocco', Journal of Development Economics 42(1), 5174.

Hajivassiliou, V. and Savignac, F. (2007), Financing constraints and a firm's decision and ability to innovate: Establishing direct and reverse effects. FMG Discussion Paper 594.

Hall, B. H. (2002), 'The financing of research and development', Oxford Review of Economic Policy 18(1), 35-51.

Hall, B. H. and Lerner, J. (2009), The financing of R\&D and innovation. NBER Working Paper 15325.

Harhoff, D. (1998), 'Are there financing constraints for R\&D and investment in German manufacturing firms', Annales d'Economie et de Statistique (49-50).

Harrison, A. E. and Mcmillan, M. (2003), 'Does direct foreign investment affect domestic credit constraints?', Journal of International Economics 61(1), 73-100.

Himmelberg, C. P. and Petersen, B. C. (1994), 'R\&D and internal finance: A panel study of small firms in high-tech industries', Review of Economics and Statistics 76(1), 38-51.

Kaplan, S. N. and Zingales, L. (2000), 'Investment-cash flow sensitivities are not valid measures of financing constraints', The Quarterly Journal of Economics 115(2), 707-712.

Lane, P. R. (2009), Innovation and Financial Globalization, Instiute for International Integration Studies, III Discussion Paper 299. 
Levine, R. (2005), Finance and growth: Theory and evidence: 12, in P. Aghion and S. Durlauf, eds, 'Handbook of Economic Growth', Vol. 1 of Handbook of Economic Growth, Elsevier, pp. 865-934.

Manova, K. (2008), Credit constraints, heterogeneous firms, and international trade. NBER Working Paper 14531.

Marin, D. and Schnitzer, M. (2002), Contracts in Trade and Transition. The resurgence of barter, Cambridge Massachusetts: MIT Press.

Marin, D. and Schnitzer, M. (2005), 'Disorganization and financial collapse', European Economic Review 49(2), 387-408.

Marin, D. and Schnitzer, M. (2006), When is FDI a Capital Flow? CEPR Discussion Paper 5755.

Melitz, M. (2003), 'The impact of trade on intra-industry reallocations and aggregate industry productivity', Econometrica 71(6), 1695-1725.

Meyer, K. E. (2002), 'Management challenges in privatization acquisitions in transition economies', Journal of World Business 37(4), 266-276.

Michie, J. (1998), 'Introduction: The internationalisation of the innovation process', International Journal of the Economics of Business 5(3), 261-277.

Mulkay, B., Hall, B. and Mairesse, J. (2001), 'Firm level investment and R\&D in France and the United States: A comparison'. NBER Working Paper 8038.

Nickell, S. (1996), 'Competition and corporate performance', Journal of Political Economy 104(4), 724-746.

OECD (2005), The measurement of scientific and technological advances, Organisation for Economic Co-operation and Development.

Sabirianova Peter, K., Svejnar, J. and Terrell, K. (2005), 'Distance to the efficiency frontier and foreign direct investment spillovers', Journal of the European Economic Association 3(2-3), 576586.

Schumpeter, J. (1943), Capitalism, Socialism, and Democracy, New York: Harper.

Stiebale, J. (2008), 'Do financial constraints matter for foreign market entry? A firm-level examination', Ruhr Economic Papers (0051).

Ughetto, E. (2008), 'Does internal finance matter for R\&D? New evidence from a panel of Italian firms', Cambridge Journal of Economics 32(6), 907-925.

Van Biesebroeck, J. (2005), 'Exporting raises productivity in sub-Saharan African manufacturing firms', Journal of International Economics 67(2), 373-391.

Wagner, J. (2007), 'Exports and productivity: A survey of the evidence from firm-level data', The World Economy 30(1), 60-82.

World Bank (1991), 'World development report: The challange of development', New York: Oxford University Press .

World Bank (1993), 'The East Asian miracle: Economic growth and public policy', New York: Oxford University Press . 
Figure 1: Measurement of financial constraints.

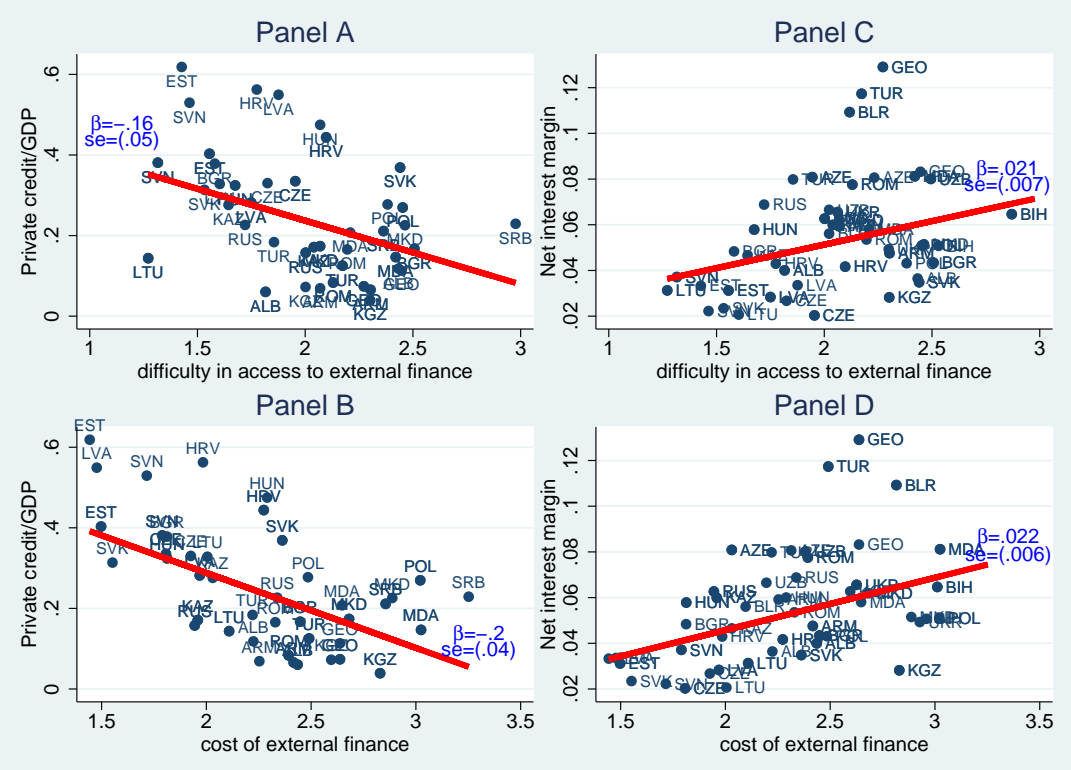

Notes: The figure presents macroeconomic indicators of financial development against the average value (weighted by employment size) of reported severity of access to external finance and cost of access to external finance across all types of firms in a given country and year (2002 and 2005). The ratio of private credit to GDP and the net interest margin (which is the accounting value of bank's net interest revenue as a share of its interest-bearing (total earning) assets) are taken from the World Bank's Database on Financial Development and Structure. The solid red line is the fitted line from the Huber robust regression with $\beta$ and se showing the estimated slope and the associated standard error. In all panels, the slope is significantly different from zero at 1 percent.

Figure 2: Financial constraints and macroeconomic outcomes.

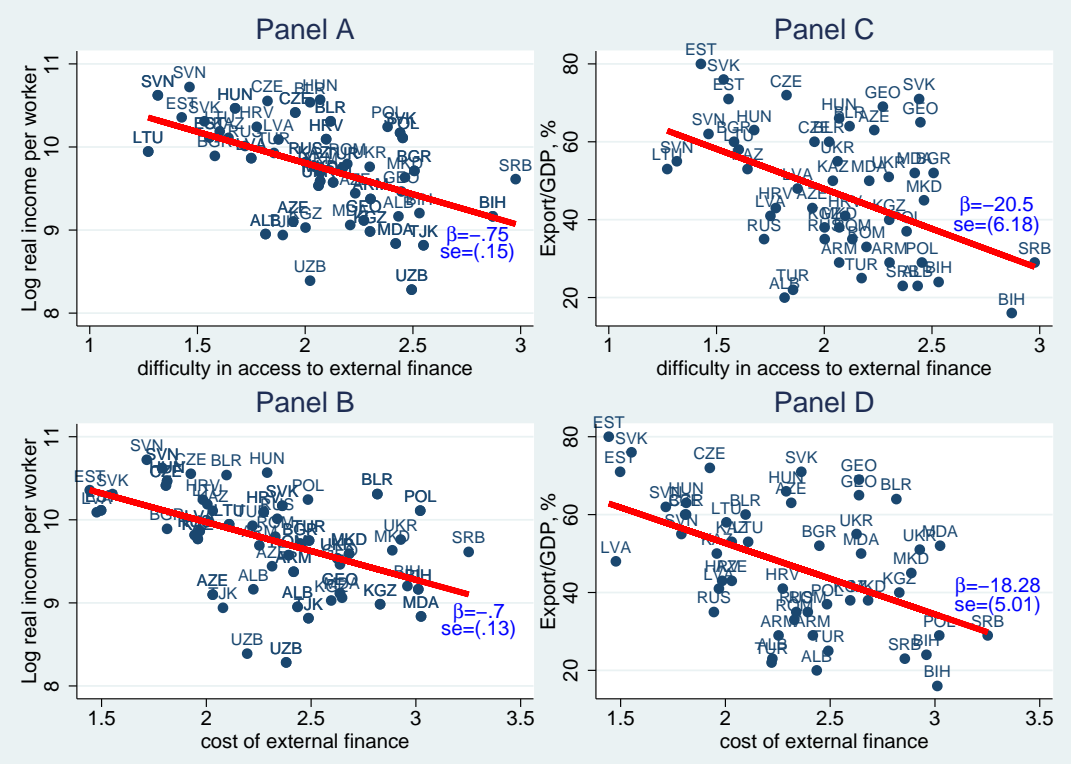

Notes: The figure presents macroeconomic outcomes against the average value (weighted by employment size) of reported severity of access to external finance and cost of access to external finance across all types of firms in a given country and year (2002 and 2005). Log real income per worker data are from the Penn World Tables. The ratio of export to GDP data are from the IMF's IFS database. The solid red line is the fitted line from the Huber robust regression with $\beta$ and se showing the estimated slope and the associated standard error. In all panels, the slope is significantly different from zero at 1 percent. 
Figure 3: Innovation, export and economic growth.

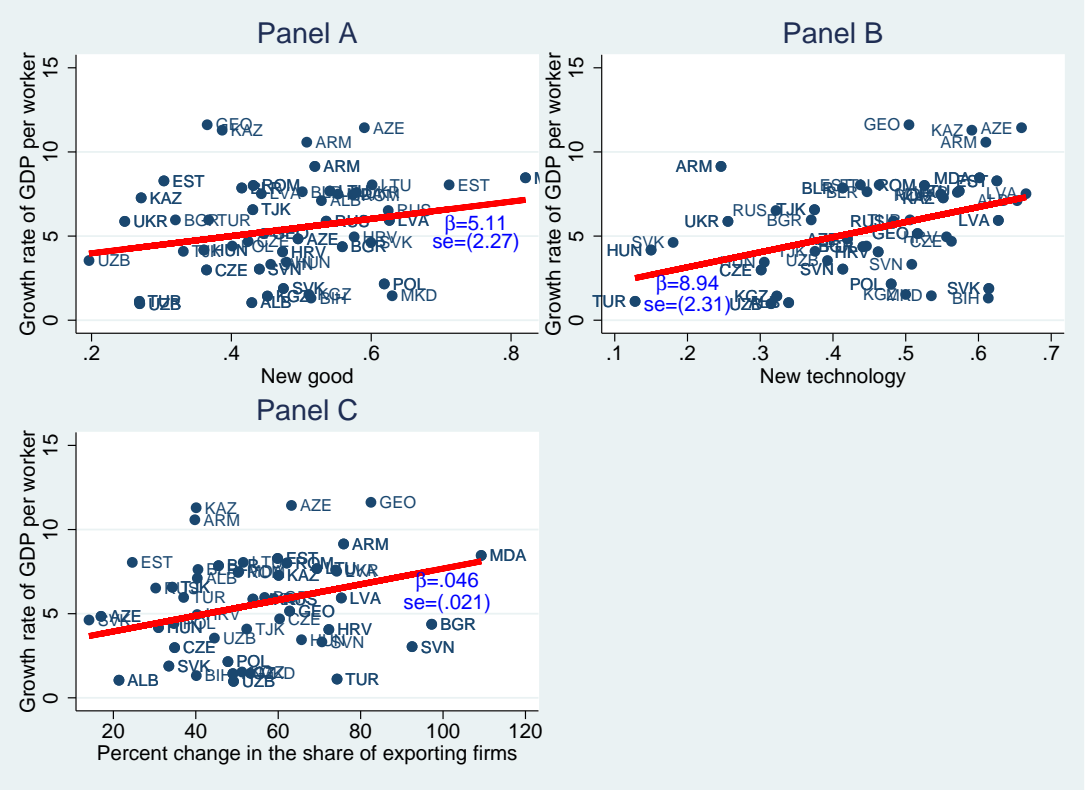

Notes: The figure presents growth rate of real GDP per worker against the average value (weighted by employment size) of intensity of New good, New technology and NewExport/Export reported in BEEPS. Growth rates of real GDP per worker data are from the Penn World Tables (version 6.3). The solid red line is the fitted line from the Huber robust regression with $\beta$ and se showing the estimated slope and the associated standard error. In all panels, the slope is significantly different from zero at 1 percent.

Figure 4: Financial constraints and reforms in financial and banking sectors.
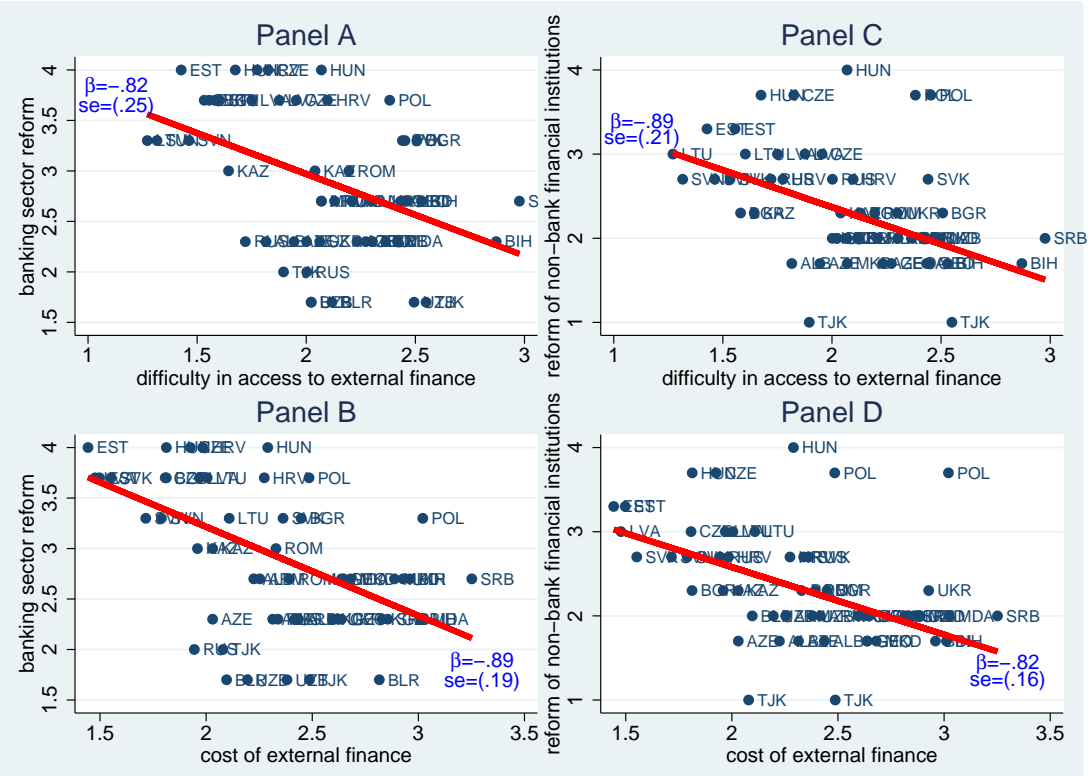

Notes: The figure presents macroeconomic outcomes against the average value (weighted by employment size) of reported severity of access to external finance and cost of access to external finance across all types of firms in a given country and year (2002 and 2005). Indices of reforms in financial and banking sectors are from the European Bank for Reconstruction and Development (EBRD). The solid red line is the fitted line from the Huber robust regression with $\beta$ and se showing the estimated slope and the associated standard error. In all panels, the slope is significantly different from zero at 1 percent. 
Table 1. The link between productivity and innovations.

\begin{tabular}{|c|c|c|c|c|c|}
\hline & \multicolumn{5}{|c|}{ Productivity } \\
\hline & $(1)$ & $(2)$ & $(3)$ & $(4)$ & $(5)$ \\
\hline \multirow[b]{2}{*}{ New technology } & \multicolumn{5}{|c|}{ Panel A: TFP } \\
\hline & $\begin{array}{c}0.038^{* *} \\
(0.018)\end{array}$ & & & $\begin{array}{c}0.032^{*} \\
(0.018)\end{array}$ & $\begin{array}{c}0.032 \\
(0.021)\end{array}$ \\
\hline New good & & $0.036^{* *}$ & & $0.033^{*}$ & 0.018 \\
\hline & & $(0.017)$ & & $(0.018)$ & $(0.021)$ \\
\hline \multirow[t]{2}{*}{ Positive R\&D spending } & & \multirow{2}{*}{\multicolumn{3}{|c|}{$\begin{array}{c}0.145^{* * *} \\
(0.024)\end{array}$}} & $0.119^{* * *}$ \\
\hline & & & & & $(0.026)$ \\
\hline Observations & 6,861 & 6,922 & 4,733 & 6,829 & 4,677 \\
\hline \multirow[t]{2}{*}{ R-squared } & 0.397 & 0.388 & 0.433 & 0.408 & 0.455 \\
\hline & \multicolumn{5}{|c|}{ Panel B: Labor productivity, $\ln (Y / L)$} \\
\hline \multirow[t]{2}{*}{ New technology } & $0.067^{* * *}$ & & & $0.050 * *$ & $0.050^{* *}$ \\
\hline & $(0.020)$ & & & $(0.021)$ & $(0.024)$ \\
\hline \multirow[t]{2}{*}{ New good } & & $0.070 * * *$ & & $0.063^{* * *}$ & $0.049 * *$ \\
\hline & & $(0.018)$ & & $(0.019)$ & $(0.023)$ \\
\hline \multirow[t]{2}{*}{ Positive R\&D spending } & & & $0.306^{* * *}$ & & $0.283^{* * *}$ \\
\hline & & & $(0.031)$ & & $(0.031)$ \\
\hline Observations & 11,816 & 11,882 & 7,335 & 11,810 & 7,272 \\
\hline R-squared & 0.606 & 0.604 & 0.680 & 0.606 & 0.682 \\
\hline
\end{tabular}

Notes: TFP measures log total factor productivity computed as log sales minus log capital, log employment, and log material input weighted by cost shares of each input and adjusted for capacity utilization (see equation (14)). Cost shares are allowed to vary by industry and country. New technology is the dummy variable equal to one if the firm reports successful development and/or adaption of new technology and zero otherwise. New good is the dummy variable equal to one if the firm reports successful introduction of a new good or service and zero otherwise. Positive RESD spending is the dummy variable equal to one if the firm reports positive research and development spending and zero otherwise. Dummy variables for interactions between year, country, and industry are included but not reported. Robust standard errors are in parentheses. ${ }^{* * *},{ }^{* *}, *$ denote significance at $0.01,0.05$, and 0.10 levels. 
Table 2. Differences in productivity between foreign and domestic private firms.

\begin{tabular}{|c|c|c|c|c|c|}
\hline \multirow[t]{2}{*}{ Dependent Variable } & All years & 2002 & 2005 & $\begin{array}{c}\text { De novo firms, } \\
\text { all years }\end{array}$ & $\begin{array}{c}\text { Control for } \\
\text { productivity } \\
\text { at } t-3, \\
\text { all years }\end{array}$ \\
\hline & $(1)$ & $(2)$ & $(3)$ & (4) & $(5)$ \\
\hline Total factor productivity & $\begin{array}{c}0.115^{* * *} \\
(0.024)\end{array}$ & $\begin{array}{l}0.096^{* *} \\
(0.042)\end{array}$ & $\begin{array}{c}0.135^{* * *} \\
(0.028)\end{array}$ & $\begin{array}{c}0.106^{* * *} \\
(0.031)\end{array}$ & $\begin{array}{c}0.061^{* * *} \\
(0.023)\end{array}$ \\
\hline Observations & 6,266 & 2,236 & 4,030 & 3,845 & 6,010 \\
\hline R-squared & 0.158 & 0.213 & 0.210 & 0.136 & 0.229 \\
\hline Labor productivity & $\begin{array}{c}0.258^{* * *} \\
(0.022)\end{array}$ & $\begin{array}{c}0.245^{* * *} \\
(0.038)\end{array}$ & $\begin{array}{c}0.266^{* * *} \\
(0.027)\end{array}$ & $\begin{array}{c}0.231^{* * *} \\
(0.028)\end{array}$ & $\begin{array}{c}0.104^{* * *} \\
(0.012)\end{array}$ \\
\hline Observations & 10,587 & 4,205 & 6,382 & 6,681 & 10,116 \\
\hline R-squared & 0.582 & 0.501 & 0.621 & 0.556 & 0.881 \\
\hline New good & $\begin{array}{c}0.072^{* * *} \\
(0.011)\end{array}$ & $\begin{array}{c}0.073^{* * *} \\
(0.016)\end{array}$ & $\begin{array}{c}0.064^{* * *} \\
(0.015)\end{array}$ & $\begin{array}{c}0.069^{* * *} \\
(0.013)\end{array}$ & $\begin{array}{c}0.074^{* * *} \\
(0.014)\end{array}$ \\
\hline Observations & 14,513 & 5,701 & 8,812 & 9,430 & 10,096 \\
\hline R-squared & 0.073 & 0.100 & 0.073 & 0.070 & 0.077 \\
\hline New technology & $\begin{array}{c}0.036^{* * *} \\
(0.011)\end{array}$ & $\begin{array}{c}0.029^{* *} \\
(0.015)\end{array}$ & $\begin{array}{c}0.046^{* * *} \\
(0.015)\end{array}$ & $\begin{array}{c}0.039^{* * *} \\
(0.013)\end{array}$ & $\begin{array}{c}0.030 * * \\
(0.013)\end{array}$ \\
\hline Observations & 14,395 & 5,689 & 8,688 & 9,342 & 9,997 \\
\hline R-squared & 0.087 & 0.095 & 0.094 & 0.089 & 0.100 \\
\hline Positive R\&D spending & $\begin{array}{c}0.110^{* * *} \\
(0.012)\end{array}$ & $\begin{array}{c}0.047^{* * *} \\
(0.013)\end{array}$ & $\begin{array}{c}0.146^{* * *} \\
(0.018)\end{array}$ & $\begin{array}{c}0.088^{* * *} \\
(0.015)\end{array}$ & $\begin{array}{c}0.108^{* * *} \\
(0.014)\end{array}$ \\
\hline Observations & 7,032 & 2,055 & 4,977 & 4,401 & 6,317 \\
\hline R-squared & 0.538 & 0.561 & 0.153 & 0.578 & 0.507 \\
\hline Export & $\begin{array}{c}0.276^{* * *} \\
(0.011)\end{array}$ & $\begin{array}{c}0.258^{* * *} \\
(0.016)\end{array}$ & $\begin{array}{c}0.287^{* * *} \\
(0.015)\end{array}$ & $\begin{array}{c}0.276^{* * *} \\
(0.013)\end{array}$ & $\begin{array}{c}0.283^{* * *} \\
(0.013)\end{array}$ \\
\hline Observations & 14,470 & 5,707 & 8,763 & 9,386 & 10,063 \\
\hline R-squared & 0.215 & 0.250 & 0.199 & 0.191 & 0.239 \\
\hline
\end{tabular}

Notes: Each panel reports the estimated OLS coefficient on the foreign ownership dummy variable for the equation with the dependent variable shown in the left column. A firm is considered foreign owned if foreigners have 50 or more percent ownership. Only private firms are included in the sample. Fixed effects for year, country, and industry are included but not reported. Total factor productivity is computed as in equation (14). Labor productivity is computed as log of sales to employment ratio. In column (5), productivity is measured as labor productivity. New technology is the dummy variable equal to one if the firm reports successful development and/or adaption of new technology and zero otherwise. New good is the dummy variable equal to one if the firm reports successful introduction of a new good or service and zero otherwise. Positive RED spending is the dummy variable equal to one if the firm reports positive research and development spending and zero otherwise. Export is the dummy variable equal to one if the firm reports positive export sales and zero otherwise. De novo firms are firms founded after 1991. Robust standard errors are in parentheses. ${ }^{* * *}, * *, *$ denote significance at $0.01,0.05$, and 0.10 levels. 
Table 3. Differences in financial constraints between foreign and domestic private firms.

\begin{tabular}{lccccc}
\hline \hline & All years & 2002 & 2005 & $\begin{array}{c}\text { De novo firms, } \\
\text { all years }\end{array}$ & $\begin{array}{c}\text { Control for } \\
\text { productivity } \\
\text { at } t-3, \\
\text { all years }\end{array}$ \\
\cline { 2 - 5 } Dependent Variable & $(1)$ & $(2)$ & $(3)$ & $(4)$ & $(5)$ \\
\hline \hline Difficulty of access & $-0.296^{* * *}$ & $-0.256^{* * *}$ & $-0.320^{* * *}$ & $-0.302^{* * *}$ & $-0.296^{* * *}$ \\
$\quad$ to external finance & $(0.026)$ & $(0.039)$ & $(0.034)$ & $(0.031)$ & $(0.032)$ \\
Observations & 13,855 & 5,433 & 8,422 & 8,985 & 9,674 \\
R-squared & 0.069 & 0.069 & 0.094 & 0.073 & 0.076 \\
\hline Cost of external finance & $-0.243^{* * *}$ & $-0.165^{* * *}$ & $-0.303^{* * *}$ & $-0.202^{* * *}$ & $-0.235^{* * *}$ \\
& $(0.026)$ & $(0.038)$ & $(0.035)$ & $(0.032)$ & $(0.032)$ \\
Observations & 13,966 & 5,498 & 8,468 & 9,026 & 9,759 \\
R-squared & 0.089 & 0.098 & 0.110 & 0.085 & 0.097 \\
\hline \hline
\end{tabular}

Notes: Each panel reports the estimated OLS coefficient on the foreign ownership dummy variable for the equation with the dependent variable shown in the left column. A firm is considered foreign owned if foreigners have 50 or more percent ownership. Only private firms are included in the sample. Fixed effects for year, country, and industry are included but not reported. In column (5), productivity is measured as labor productivity. De novo firms are firms founded after 1991. Robust standard errors are in parentheses. $* * *, * *, *$ denote significance at $0.01,0.05$, and 0.10 levels. 


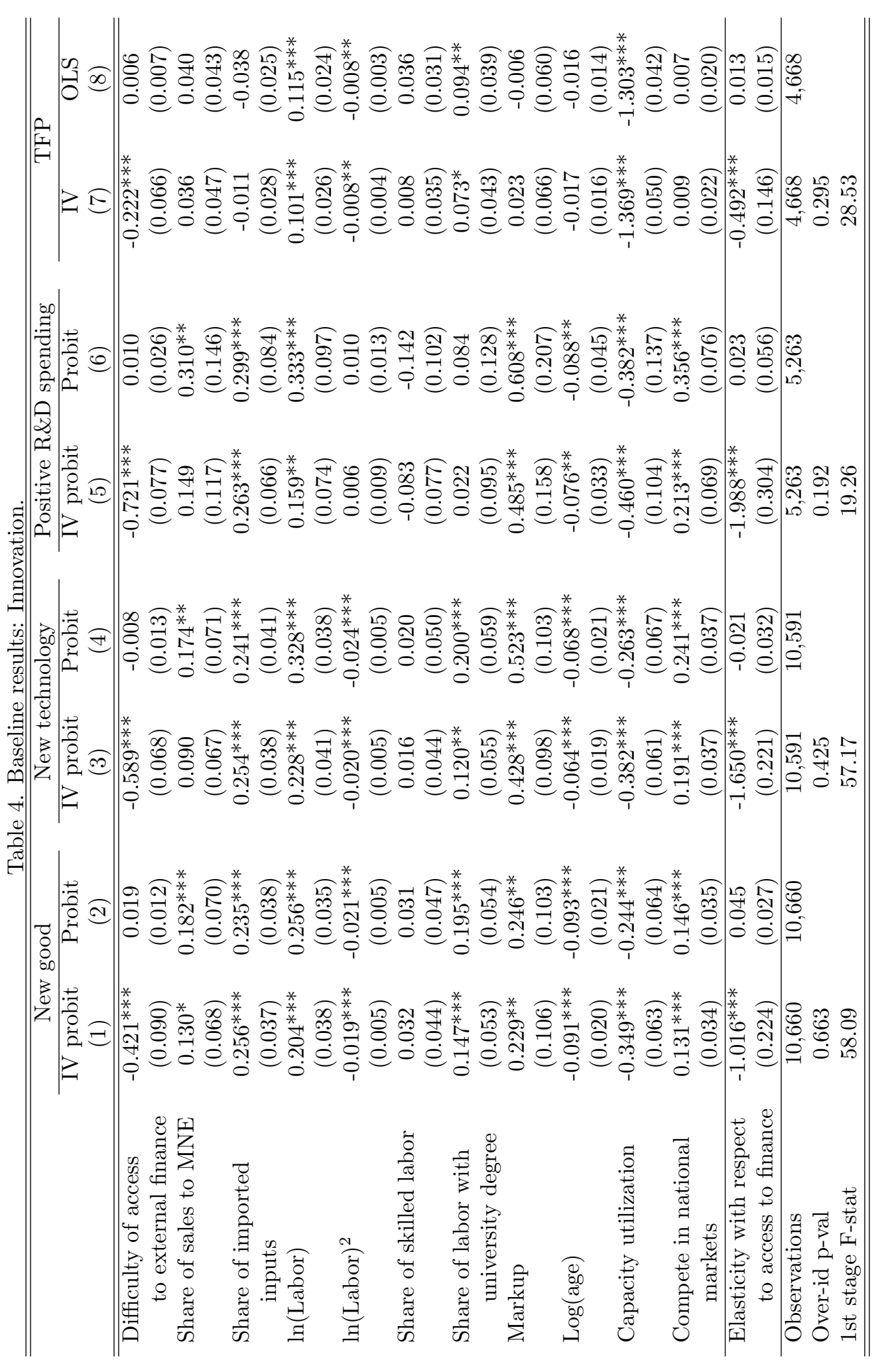

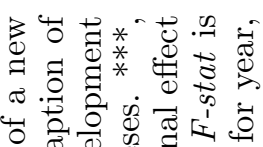

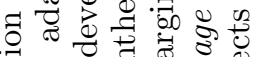

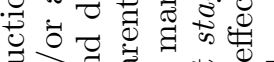

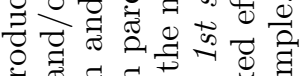
牙 $\exists$ 屯ี

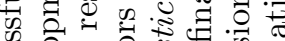

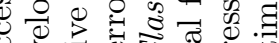

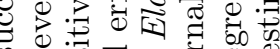
की

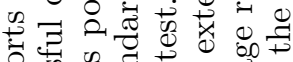

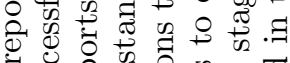

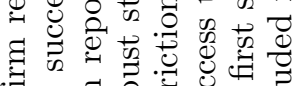

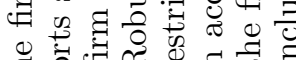

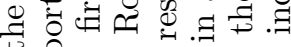

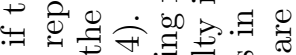

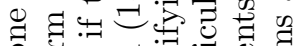
의

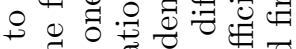
ఫే

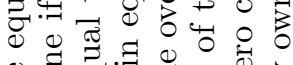
응 छ.

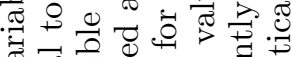
సี శี. > क्ष व $>$ वे

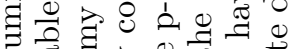

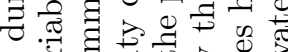

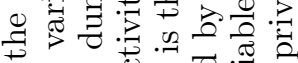
.

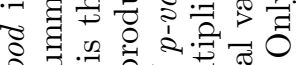
उ 0 .

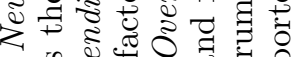

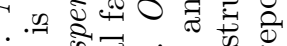
10 के $=-000$.

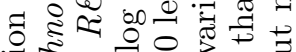

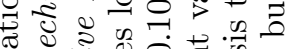

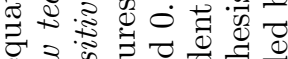
ช 3 के

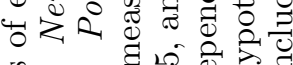
क $\dot{0}$ व घ

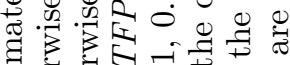

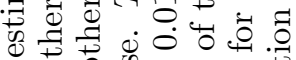

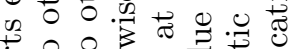
눈

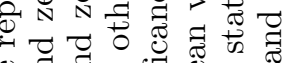

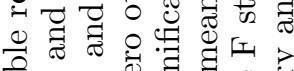
๘ 80.000

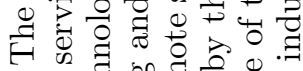

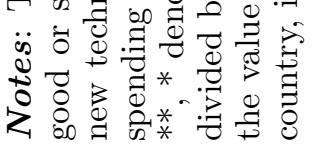


Table 5. Baseline results: Export.

\begin{tabular}{|c|c|c|c|c|}
\hline & \multicolumn{2}{|c|}{ Export } & \multicolumn{2}{|c|}{ New export } \\
\hline & $\begin{array}{l}\text { IV probit } \\
(1)\end{array}$ & $\begin{array}{c}\text { Probit } \\
(2)\end{array}$ & $\begin{array}{l}\text { IV probit } \\
(3)\end{array}$ & $\begin{array}{c}\text { Probit } \\
(4)\end{array}$ \\
\hline Difficulty of access & $-0.260^{* *}$ & 0.009 & $-0.382^{* * *}$ & 0.001 \\
\hline to external finance & $(0.124)$ & $(0.014)$ & $(0.129)$ & $(0.018)$ \\
\hline Share of sales to MNE & $\begin{array}{c}0.500^{* * *} * \\
(0.083)\end{array}$ & $\begin{array}{c}0.489^{* * *} \\
(0.075)\end{array}$ & $\begin{array}{c}0.364^{* * *} \\
(0.092)\end{array}$ & $\begin{array}{c}0.466^{* * *} \\
(0.083)\end{array}$ \\
\hline Share of imported inputs & $\begin{array}{c}0.475^{* * *} \\
(0.046)\end{array}$ & $\begin{array}{c}0.446^{* * *} \\
(0.046)\end{array}$ & $\begin{array}{c}0.549 * * * \\
(0.057)\end{array}$ & $\begin{array}{c}0.465^{* * *} \\
(0.054)\end{array}$ \\
\hline $\ln$ (Labor) & $\begin{array}{c}0.347^{* * *} \\
(0.049)\end{array}$ & $\begin{array}{c}0.363^{* * *} \\
(0.044)\end{array}$ & $\begin{array}{c}0.271^{* * *} \\
(0.058)\end{array}$ & $\begin{array}{c}0.312^{* * *} \\
(0.052)\end{array}$ \\
\hline $\ln (\text { Labor })^{2}$ & $\begin{array}{l}-0.010^{*} \\
(0.006)\end{array}$ & $\begin{array}{l}-0.011^{*} \\
(0.006)\end{array}$ & $\begin{array}{l}-0.008 \\
(0.006)\end{array}$ & $\begin{array}{l}-0.010 \\
(0.006)\end{array}$ \\
\hline Share of skilled labor & $\begin{array}{c}-0.121^{* *} \\
(0.060)\end{array}$ & $\begin{array}{c}-0.119 * * \\
(0.059)\end{array}$ & $\begin{array}{l}-0.090 \\
(0.072)\end{array}$ & $\begin{array}{l}-0.112 \\
(0.072)\end{array}$ \\
\hline $\begin{array}{l}\text { Share of labor with } \\
\text { university degree }\end{array}$ & $\begin{array}{c}0.562^{* * *} \\
(0.076)\end{array}$ & $\begin{array}{c}0.591^{* * *} \\
(0.069)\end{array}$ & $\begin{array}{c}0.538^{* * *} \\
(0.095)\end{array}$ & $\begin{array}{c}0.542^{* * *} \\
(0.084)\end{array}$ \\
\hline Markup & $\begin{array}{c}0.154 \\
(0.121)\end{array}$ & $\begin{array}{c}0.128 \\
(0.122)\end{array}$ & $\begin{array}{c}0.035 \\
(0.154)\end{array}$ & $\begin{array}{c}0.083 \\
(0.152)\end{array}$ \\
\hline Log(age) & $\begin{array}{c}0.097^{* * *} \\
(0.025)\end{array}$ & $\begin{array}{c}0.105^{* * *} \\
(0.024)\end{array}$ & $\begin{array}{c}0.032 \\
(0.028)\end{array}$ & $\begin{array}{c}0.041 \\
(0.028)\end{array}$ \\
\hline Capacity utilization & $\begin{array}{c}-0.366^{* * *} \\
(0.085)\end{array}$ & $\begin{array}{c}-0.226^{* * *} \\
(0.079)\end{array}$ & $\begin{array}{c}-0.596^{* * *} \\
(0.096)\end{array}$ & $\begin{array}{c}-0.420^{* * *} \\
(0.096)\end{array}$ \\
\hline $\begin{array}{l}\text { Compete in national } \\
\text { markets }\end{array}$ & $\begin{array}{c}0.410^{* * *} \\
(0.050) \\
\end{array}$ & $\begin{array}{c}0.431^{* * *} \\
(0.046)\end{array}$ & $\begin{array}{c}0.326^{* * *} \\
(0.063) \\
\end{array}$ & $\begin{array}{c}0.384^{* * *} \\
(0.058)\end{array}$ \\
\hline $\begin{array}{l}\text { Elasticity with respect } \\
\text { to access to finance }\end{array}$ & $\begin{array}{c}-0.646^{* *} \\
(0.348)\end{array}$ & $\begin{array}{c}0.022 \\
(0.035)\end{array}$ & $\begin{array}{c}-1.058^{* *} \\
(0.571)\end{array}$ & $\begin{array}{c}0.002 \\
(0.042)\end{array}$ \\
\hline Observations & 10,622 & 10,947 & 10,200 & 10,520 \\
\hline Over-id p-val & 0.395 & & 0.491 & \\
\hline 1st stage F-stat & 36.67 & & 39.46 & \\
\hline
\end{tabular}

Notes: The table reports estimates of equation (15). Export is the dummy variable equal to one if the firm reports positive export sales and zero otherwise. New Export is the dummy variable equal to one if the firm started exporting goods over last three years and zero otherwise. Elasticity is the marginal effect divided by the mean value of the dependent variable (unconditional probability of success) and multiplied by the mean value of difficulty in access to external finance. Fixed effects for year, country, industry and location are included but not reported. Robust standard errors are in parentheses. $* * *, * *, *$ denote significance at $0.01,0.05$, and 0.10 levels. 


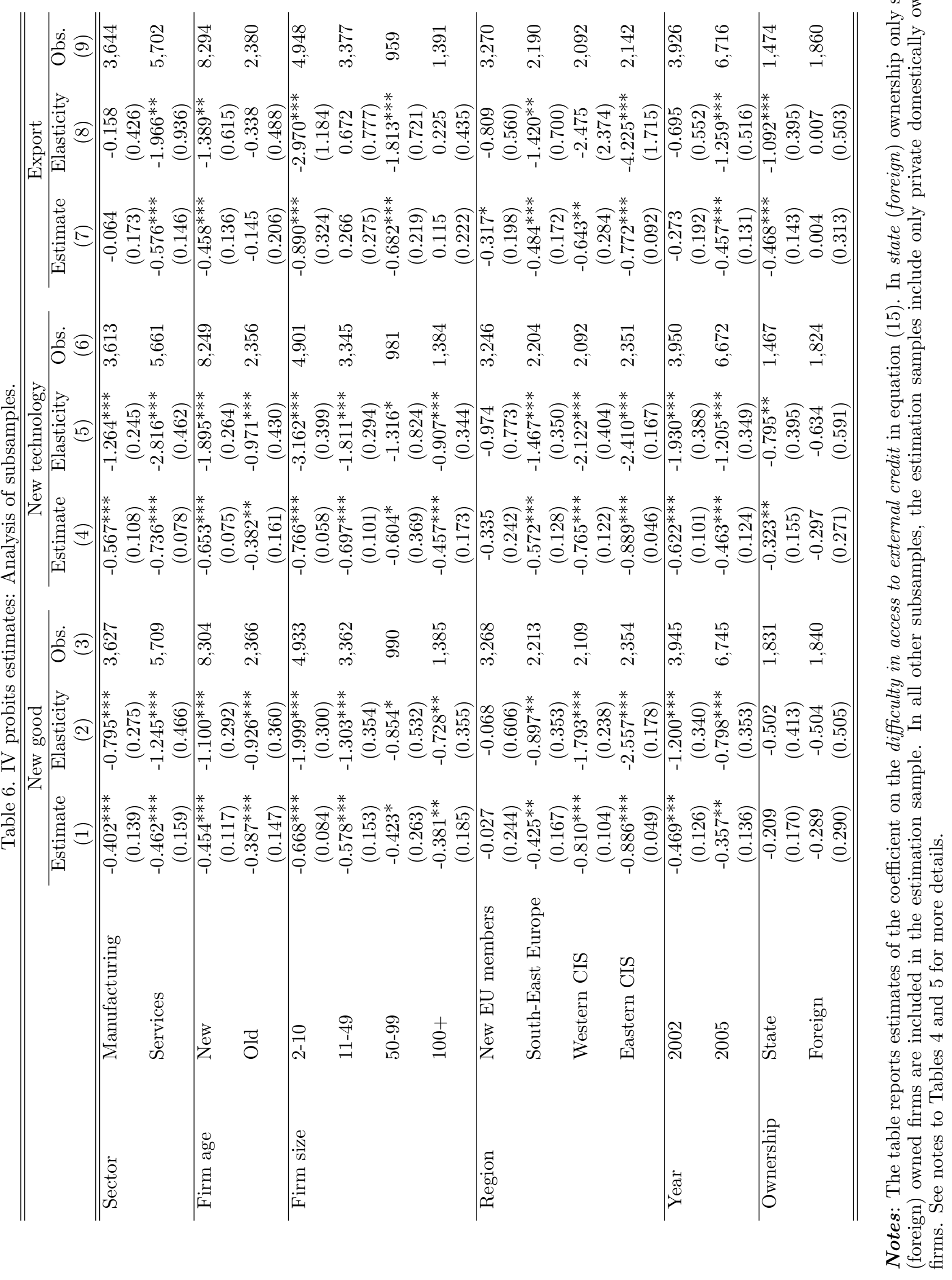




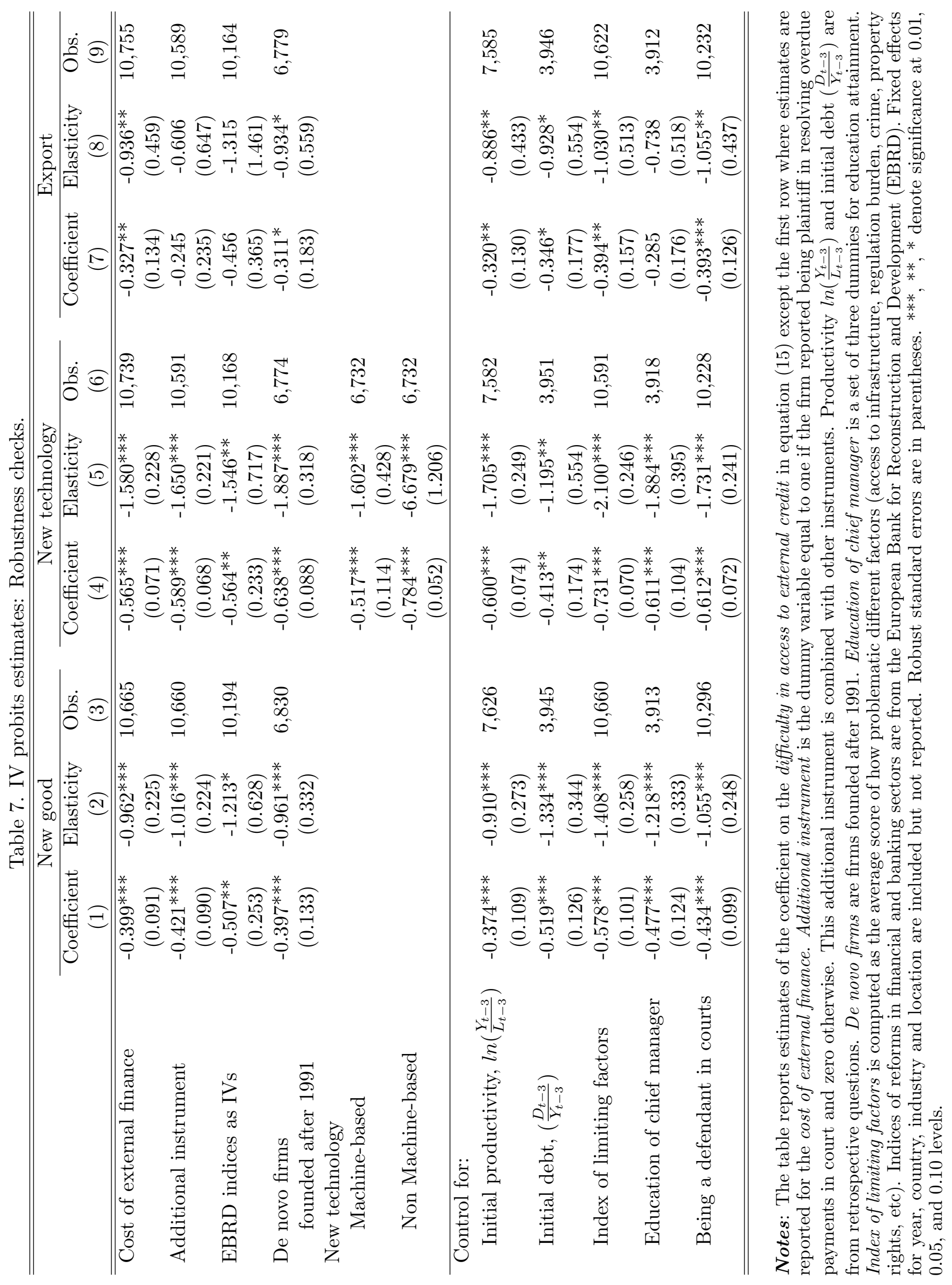




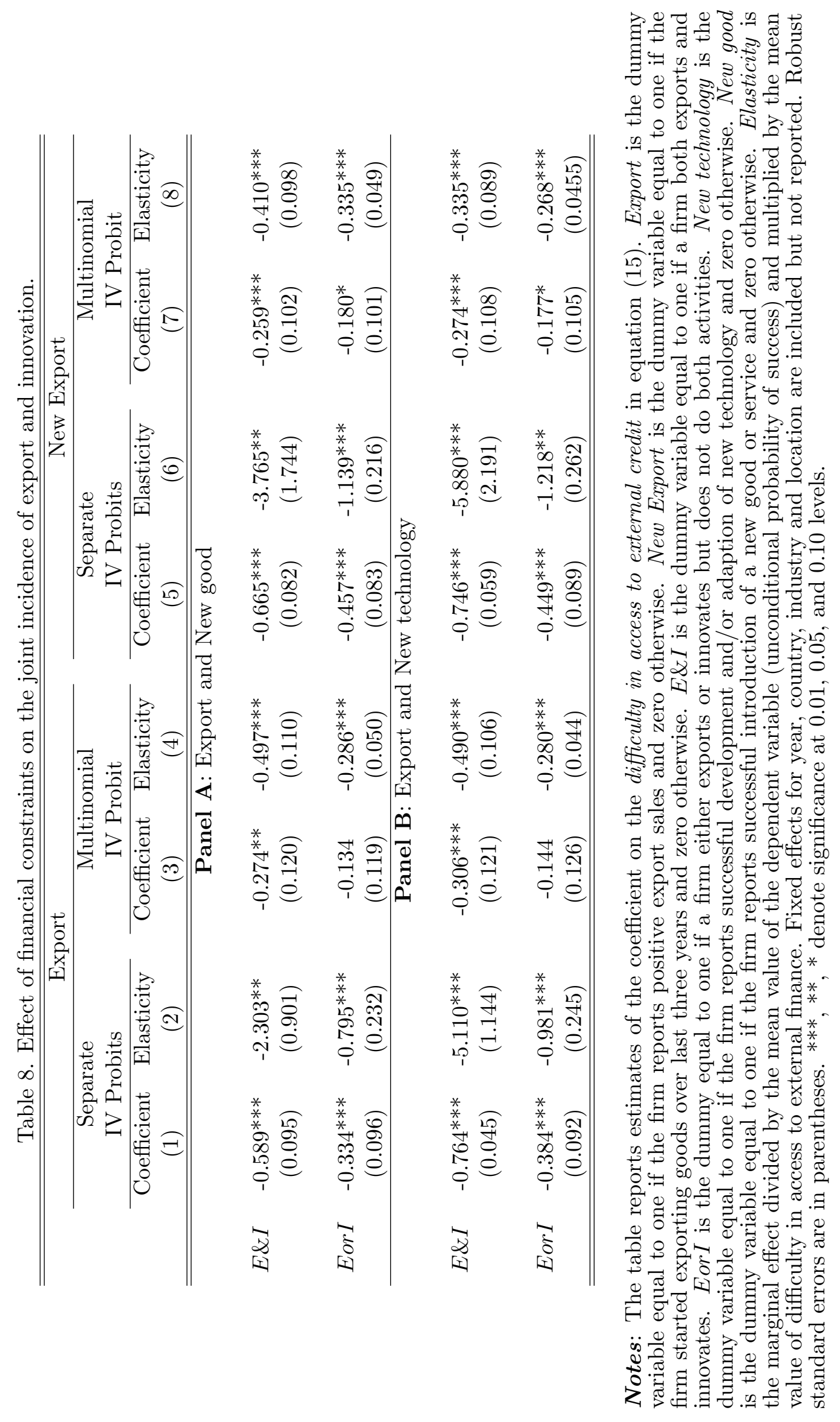




\section{Appendix Tables}

Appendix table A1. Descriptive statistics.

\begin{tabular}{|c|c|c|}
\hline & Mean & St.Dev. \\
\hline \multicolumn{3}{|l|}{ Innovation Variables } \\
\hline New Product & 0.374 & 0.484 \\
\hline New Technology & 0.302 & 0.459 \\
\hline Positive R\&D spending & 0.370 & 0.482 \\
\hline Total factor productivity & 1.668 & 0.710 \\
\hline \multicolumn{3}{|l|}{ Measures of financial constraints } \\
\hline Difficulty of access to external finance & 2.333 & 1.145 \\
\hline Cost of external finance & 2.574 & 1.129 \\
\hline \multicolumn{3}{|l|}{ Export activity } \\
\hline Export & 0.204 & 0.403 \\
\hline New Export & 0.095 & 0.294 \\
\hline \multicolumn{3}{|l|}{ Vertical Transfer of Capability } \\
\hline Share of sales to multinationals (MNEs) & 0.066 & 0.196 \\
\hline Share of imported inputs & 0.258 & 0.359 \\
\hline \multicolumn{3}{|l|}{ Controls } \\
\hline $\ln ($ Labor) & 3.000 & 1.604 \\
\hline $\ln (\text { Labor })^{2}$ & 11.577 & 11.530 \\
\hline Share of skilled workers & 0.487 & 0.309 \\
\hline Share of workers with university education & 0.272 & 0.290 \\
\hline $\log ($ age $)$ & 2.367 & 0.777 \\
\hline Compete in national markets & 0.667 & 0.471 \\
\hline Markup & 0.209 & 0.118 \\
\hline Capacity utilization & 0.794 & 0.177 \\
\hline \multicolumn{3}{|l|}{ Location } \\
\hline Capital & 0.313 & 0.464 \\
\hline Other, over 1 million & 0.060 & 0.237 \\
\hline Other, $250,000-1,000,000$ & 0.157 & 0.364 \\
\hline Other, 50,000-250,000 & 0.224 & 0.417 \\
\hline Under 50,000 & 0.241 & 0.428 \\
\hline \multicolumn{3}{|l|}{ Instrumental variables } \\
\hline Overdue dummy & 0.148 & 0.355 \\
\hline NTPcustomer dummy & 0.040 & 0.136 \\
\hline NTPsupplier dummy & 0.044 & 0.154 \\
\hline Plaintiff dummy & 0.198 & 0.399 \\
\hline
\end{tabular}


Appendix table A2. Unconditional probabilities of innovation.

\begin{tabular}{lccc}
\hline \hline & $\begin{array}{c}\text { New } \\
\text { technology }\end{array}$ & $\begin{array}{c}\text { New } \\
\text { good }\end{array}$ & $\begin{array}{c}\text { R\&D } \\
\text { expenditure }\end{array}$ \\
\cline { 2 - 4 } & $(1)$ & $(2)$ & $(3)$ \\
\hline \hline Sector & & & \\
$\quad$ Manufacturing & 0.492 & 0.431 & 0.431 \\
$\quad$ Services & 0.314 & 0.227 & 0.302 \\
Firm age & & & \\
$\quad$ New & 0.300 & 0.375 & 0.336 \\
Old & 0.329 & 0.372 & 0.459 \\
Firm Size & & & \\
2-10 & 0.207 & 0.298 & 0.188 \\
11-50 & 0.333 & 0.395 & 0.351 \\
51-100 & 0.376 & 0.440 & 0.450 \\
100+ & 0.430 & 0.459 & 0.695 \\
Ownership & & & \\
Private domestic & 0.299 & 0.366 & 0.307 \\
$\quad$ State & 0.309 & 0.320 & 0.561 \\
$\quad$ Foreign & 0.352 & 0.463 & 0.582 \\
Region & & & \\
New EU members & 0.262 & 0.357 & 0.355 \\
South-East Europe & 0.361 & 0.456 & 0.353 \\
Western CIS & 0.322 & 0.417 & 0.500 \\
Eastern CIS & 0.326 & 0.314 & 0.309 \\
\hline \hline
\end{tabular}


Appendix table A3. First stage regression.

\begin{tabular}{|c|c|c|c|c|c|c|}
\hline & $\begin{array}{c}\text { New } \\
\text { good } \\
(1)\end{array}$ & $\begin{array}{c}\text { New } \\
\text { technology }\end{array}$ & $\begin{array}{c}\text { Positive } \\
\text { R\&D } \\
\text { spending } \\
(3)\end{array}$ & TFP & Export & $\begin{array}{c}\text { New } \\
\text { export } \\
(6)\end{array}$ \\
\hline Overdue dummy & $\begin{array}{c}0.290^{* * *} \\
(0.031)\end{array}$ & $\begin{array}{c}0.288^{* * *} \\
(0.031)\end{array}$ & $\begin{array}{c}0.295^{* * *} \\
(0.042)\end{array}$ & $\begin{array}{c}0.302^{* * *} \\
(0.046)\end{array}$ & $\begin{array}{c}0.303^{* * *} \\
(0.030)\end{array}$ & $\begin{array}{c}0.317^{* * *} \\
(0.030)\end{array}$ \\
\hline NTPcustomer dummy & $\begin{array}{c}0.055 \\
(0.122)\end{array}$ & $\begin{array}{c}0.088 \\
(0.121)\end{array}$ & $\begin{array}{l}-0.018 \\
(0.169)\end{array}$ & $\begin{array}{l}-0.172 \\
(0.184)\end{array}$ & $\begin{array}{c}0.059 \\
(0.121)\end{array}$ & $\begin{array}{c}0.011 \\
(0.124)\end{array}$ \\
\hline NTPsupplier dummy & $\begin{array}{c}0.232^{* *} \\
(0.108)\end{array}$ & $\begin{array}{l}0.206^{*} \\
(0.107)\end{array}$ & $\begin{array}{c}0.248 \\
(0.154)\end{array}$ & $\begin{array}{c}0.395^{* *} \\
(0.165)\end{array}$ & $\begin{array}{l}0.210^{*} \\
(0.110)\end{array}$ & $\begin{array}{c}0.267^{* *} \\
(0.109)\end{array}$ \\
\hline Share of sales to MNE & $\begin{array}{l}-0.052 \\
(0.057)\end{array}$ & $\begin{array}{l}-0.056 \\
(0.057)\end{array}$ & $\begin{array}{l}-0.042 \\
(0.083)\end{array}$ & $\begin{array}{c}0.006 \\
(0.086)\end{array}$ & $\begin{array}{l}-0.045 \\
(0.056)\end{array}$ & $\begin{array}{l}-0.054 \\
(0.057)\end{array}$ \\
\hline $\begin{array}{l}\text { Share of imported } \\
\text { inputs }\end{array}$ & $\begin{array}{c}0.146^{* * *} \\
(0.033)\end{array}$ & $\begin{array}{c}0.148^{* * *} \\
(0.033)\end{array}$ & $\begin{array}{c}0.152^{* * *} \\
(0.047)\end{array}$ & $\begin{array}{c}0.159^{* * *} \\
(0.049)\end{array}$ & $\begin{array}{c}0.145^{* * *} \\
(0.032)\end{array}$ & $\begin{array}{c}0.154^{* * *} \\
(0.033)\end{array}$ \\
\hline $\ln ($ Labor $)$ & $\begin{array}{l}-0.041 \\
(0.027)\end{array}$ & $\begin{array}{l}-0.036 \\
(0.027)\end{array}$ & $\begin{array}{l}-0.055 \\
(0.040)\end{array}$ & $\begin{array}{l}-0.064 \\
(0.044)\end{array}$ & $\begin{array}{l}-0.041 \\
(0.027)\end{array}$ & $\begin{array}{l}-0.034 \\
(0.027)\end{array}$ \\
\hline $\ln (\text { Labor })^{2}$ & $\begin{array}{l}-0.003 \\
(0.004)\end{array}$ & $\begin{array}{l}-0.004 \\
(0.004)\end{array}$ & $\begin{array}{l}-0.001 \\
(0.005)\end{array}$ & $\begin{array}{l}-0.000 \\
(0.006)\end{array}$ & $\begin{array}{l}-0.003 \\
(0.003)\end{array}$ & $\begin{array}{l}-0.003 \\
(0.003)\end{array}$ \\
\hline Share of skilled labor & $\begin{array}{c}0.011 \\
(0.039)\end{array}$ & $\begin{array}{c}0.003 \\
(0.039)\end{array}$ & $\begin{array}{c}0.000 \\
(0.057)\end{array}$ & $\begin{array}{c}-0.128^{* *} \\
(0.061)\end{array}$ & $\begin{array}{c}0.018 \\
(0.039)\end{array}$ & $\begin{array}{c}0.018 \\
(0.039)\end{array}$ \\
\hline $\begin{array}{l}\text { Share of labor } \\
\text { with university degree }\end{array}$ & $\begin{array}{l}-0.029 \\
(0.045)\end{array}$ & $\begin{array}{l}-0.029 \\
(0.045)\end{array}$ & $\begin{array}{l}-0.007 \\
(0.067)\end{array}$ & $\begin{array}{l}-0.075 \\
(0.073)\end{array}$ & $\begin{array}{l}-0.025 \\
(0.045)\end{array}$ & $\begin{array}{l}-0.002 \\
(0.046)\end{array}$ \\
\hline Markup & $\begin{array}{c}0.038 \\
(0.088)\end{array}$ & $\begin{array}{c}0.045 \\
(0.088)\end{array}$ & $\begin{array}{c}0.138 \\
(0.115)\end{array}$ & $\begin{array}{c}0.114 \\
(0.125)\end{array}$ & $\begin{array}{c}0.033 \\
(0.087)\end{array}$ & $\begin{array}{c}0.014 \\
(0.087)\end{array}$ \\
\hline $\log ($ age $)$ & $\begin{array}{l}-0.024 \\
(0.017)\end{array}$ & $\begin{array}{l}-0.022 \\
(0.017)\end{array}$ & $\begin{array}{l}-0.027 \\
(0.024)\end{array}$ & $\begin{array}{l}-0.009 \\
(0.026)\end{array}$ & $\begin{array}{l}-0.022 \\
(0.016)\end{array}$ & $\begin{array}{l}-0.021 \\
(0.017)\end{array}$ \\
\hline $\begin{array}{l}\text { Compete in national } \\
\text { markets }\end{array}$ & $\begin{array}{c}0.003 \\
(0.029)\end{array}$ & $\begin{array}{c}0.000 \\
(0.029)\end{array}$ & $\begin{array}{l}-0.036 \\
(0.040)\end{array}$ & $\begin{array}{c}0.011 \\
(0.043)\end{array}$ & $\begin{array}{c}0.010 \\
(0.029)\end{array}$ & $\begin{array}{c}0.002 \\
(0.029)\end{array}$ \\
\hline Capacity utilization & $\begin{array}{c}-0.279^{* * *} \\
(0.054)\end{array}$ & $\begin{array}{c}-0.281^{* * *} \\
(0.055)\end{array}$ & $\begin{array}{c}-0.306^{* * *} \\
(0.078)\end{array}$ & $\begin{array}{c}-0.273^{* * *} \\
(0.084)\end{array}$ & $\begin{array}{c}-0.287^{* * *} \\
(0.054)\end{array}$ & $\begin{array}{c}-0.295^{* * *} \\
(0.055)\end{array}$ \\
\hline Observations & 10,690 & 10,591 & 5,263 & 4,668 & 10,622 & 10,200 \\
\hline
\end{tabular}

Notes: The table reports the first stage estimation results for estimates reported in Tables 3 and 4 . Overdue dummy is the dummy variable equal to one if a firm has overdue payments to suppliers. NTPcustomer dummy is the share of payments from customers settled by debt swaps or offsets and exchange of goods for goods (barter). NTPsupplier dummy is the share of payments to suppliers settled by debt swaps or offsets and exchange of goods for goods (barter). TFP measures log total factor productivity computed as log sales minus log capital, log employment, and log material input weighted by cost shares of each input and adjusted for capacity utilization (see equation (14)). Cost shares are allowed to vary by industry and country. New technology is the dummy variable equal to one if the firm reports successful development and/or adaption of new technology and zero otherwise. New good is the dummy variable equal to one if the firm reports successful introduction of a new good or service and zero otherwise. Positive RESD spending is the dummy variable equal to one if the firm reports positive research and development spending and zero otherwise. Only private domestically owned firms are included in the estimation sample. Robust standard errors are in parentheses. ${ }^{* *},{ }^{* *}, *$ denote significance at $0.01,0.05$, and 0.10 levels. 
Appendix table A4. Description of variables.

\begin{tabular}{|c|c|c|}
\hline $\begin{array}{l}\text { Variable } \\
\text { Name }\end{array}$ & $\begin{array}{l}\text { Variable } \\
\text { Definition }\end{array}$ & BEEPS question \\
\hline New good & $\begin{array}{l}\text { New product or up- } \\
\text { grade existing prod- } \\
\text { uct }\end{array}$ & $\begin{array}{l}\text { Dummy variable }=1 \text { if 'yes' to any of the two questions: Has your } \\
\text { company undertaken any of the following initiatives over the last } \\
36 \text { months? } \\
\text { - Developed successfully a major new product line } \\
\text { - Upgraded an existing product line }\end{array}$ \\
\hline $\begin{array}{l}\text { New tech- } \\
\text { nology }\end{array}$ & $\begin{array}{l}\text { New technology is } \\
\text { implemented }\end{array}$ & $\begin{array}{l}\text { Dummy variable }=1 \text { if answer is affirmative to question: Has your } \\
\text { firm acquired new production technology over the last } 36 \text { months? }\end{array}$ \\
\hline SMNE & $\begin{array}{l}\text { Share of sales to } \\
\text { MNEs }\end{array}$ & $\begin{array}{l}\text { Share of sales to multinationals located in your country (not in- } \\
\text { cluding your parent company, if applicable) }\end{array}$ \\
\hline Import & Import share & $\begin{array}{l}\text { Share of your firm's material inputs and supplies that are imported } \\
\text { directly or indirectly through a distributor }\end{array}$ \\
\hline Export & Export status & $\begin{array}{l}\text { Dummy variable }=1 \text { if a firm reports positive export sales in } \\
\text { "What is the share of your firm's sales are exported directly or } \\
\text { indirectly through a distributor?" }\end{array}$ \\
\hline NewExport & Start exporting & $\begin{array}{l}\text { Dummy variable }=1 \text { if a firm responds to "Has your started to } \\
\text { export to a new country during the last } 36 \text { months?" }\end{array}$ \\
\hline $\mathrm{L}$ & Labor, 3 yrs ago & Number of permanent and temporary employees 36 month ago \\
\hline $\mathrm{CU}$ & $\begin{array}{l}\text { Capacity utilization, } \\
3 \text { yrs ago }\end{array}$ & $\begin{array}{l}\text { Level of utilization of facilities/man power relative to the maxi- } \\
\text { mum output possible using its facilities/man power } 36 \text { month ago }\end{array}$ \\
\hline SKILL & $\begin{array}{l}\text { Share of skilled } \\
\text { workers, } 3 \text { yrs ago }\end{array}$ & $\begin{array}{l}\text { What share of your current permanent, full-time workers were } \\
\text { skilled workers } 36 \text { months ago? }\end{array}$ \\
\hline EDU & $\begin{array}{l}\text { Share of workers } \\
\text { with higher educa- } \\
\text { tion, 3yrs ago }\end{array}$ & $\begin{array}{l}\text { What share of the workforce at your firm had some university } \\
\text { education } 36 \text { months ago? }\end{array}$ \\
\hline Age & Firm's age & $\begin{array}{l}\text { Year of survey minus the year when the firm was established (min- } \\
\text { imum age is two years). For the year established: In what year } \\
\text { did your firm begin operations in this country? }\end{array}$ \\
\hline CNM & $\begin{array}{l}\text { Compete in national } \\
\text { markets }\end{array}$ & $\begin{array}{l}\text { Dummy variable }=1 \text { if a firm responds 'Yes' to "Does your firm } \\
\text { compete in the national market (i.e. whole country) for its main } \\
\text { product line or service or does it serve primarily the local market } \\
\text { (i.e. region, city, or neighborhood)?" }\end{array}$ \\
\hline LOC & Location & $\begin{array}{l}\text { Type of location: Capital; Other city over } 1 \text { million; Other } \\
\text { 250,000-1,000,000; Other 50,000-250,000; Under } 50,000\end{array}$ \\
\hline Markup & Markup & $\begin{array}{l}\text { Considering your main product line or main line of services in the } \\
\text { domestic market, by what margin does your sales price exceed } \\
\text { your operating costs (i.e., the cost of material inputs plus wage } \\
\text { costs but not overhead and depreciation)? }\end{array}$ \\
\hline
\end{tabular}




\section{Mathematical Appendix}

\section{Basic Setup}

Consider the following example of a firm that is competing in a monopolistic competition environment à la Dixit Stiglitz. Consumers have a preference for variety and hence there are total expenditures $Y$ on a diversified bundle of goods. Solving the utility maximization problem of a representative consumer, we can derive the demand function for the firm as

$$
x=\frac{Y p^{-\sigma}}{P^{1-\sigma}},
$$

where $p$ is the price charged by the firm, $P$ is the price index of all varieties' prices, and $\sigma$ is the elasticity of substitution.

Firms produce at a constant marginal cost $c$. If the firm innovates, it reduces this marginal cost to $\alpha c<c$, with $\alpha<1$. If production is financed with external funds, the cost of each unit is increased by a factor of $\gamma$, with $\gamma>1$. Profits are given by

$$
\pi_{0}=p x-c x-F_{I}
$$

if internal funds are used and no innovation is carried out. Firms set prices to maximize their profits. Consider the first order condition

$$
\frac{d \pi_{0}}{d p}=x+(p-c) \frac{d x}{d p}=0
$$

From (16) we can derive

$$
\frac{d x}{d p}=-\sigma \frac{Y p^{-\sigma-1}}{P^{1-\sigma}}
$$

using the fact that the price index does not change if a single firm changes its price, due to the continuum of firms.

Plugging (19) and (16) into (18), we can solve for the optimal price

$$
p=c \frac{\sigma}{\sigma-1}
$$

Now, using (20) and (16), we can determine the profit as

$$
\pi_{0}=\frac{Y}{\sigma}\left(\frac{p}{P}\right)^{1-\sigma}
$$

Consider next the case where external finance is used. The only difference with respect to $\pi_{0}$ is that now the constant marginal cost is multiplied by $\gamma$ and so is the optimal price set by the firm. Hence

$$
\pi_{\gamma}=\gamma^{(1-\sigma)} \pi_{0}
$$

Similarly, we can determine $\pi_{0}^{I}=\alpha^{(1-\sigma)} \pi_{0}$ and $\pi_{\gamma}^{I}=(\alpha \gamma)^{(1-\sigma)} \pi_{0}$. Thus, assumption 1 is confirmed by

$$
\frac{d\left(\pi_{\gamma}^{I}-\pi_{\gamma}\right)}{d \gamma}=(1-\sigma) \gamma^{(-\sigma)}\left(\alpha^{1-\sigma}-1\right) \pi_{0}<0
$$

Note that $\frac{d \Delta_{\pi}}{d \delta_{L}}=-\left(1-\gamma^{1-\sigma}\right)\left(\alpha^{1-\sigma}-1\right) \frac{Y}{\sigma}\left(\frac{p}{P}\right)^{1-\sigma}<0$ when $\gamma>1, \alpha<1$ and $\sigma>1$. 


\section{Interaction of export and innovation}

To see that Assumption 2 is reasonable, consider again $\pi_{0}=\frac{Y}{\sigma}\left(\frac{p}{P}\right)^{1-\sigma}$ as determined above, and $\pi_{0}^{I}=\frac{Y}{\sigma}\left(\frac{\alpha c}{P} \frac{\sigma}{\sigma-1}\right)^{1-\sigma}=\frac{Y}{\sigma}\left(\frac{\alpha c}{P} \frac{\sigma}{\sigma-1}\right)^{1-\sigma}=\alpha^{1-\sigma} \pi_{0}>\pi_{0}$. Consider next the firm's payoff in case of exporting. To simplify notation, suppose that the foreign market is symmetric to the domestic market, such that the exporting firm is now confronted with an increase in demand, represented by an increase in total expenditures $m Y>Y$. Thus, we can write

$$
\pi_{0}^{E}=m \pi_{0}=\frac{m Y}{\sigma}\left(\frac{c}{P} \frac{\sigma}{\sigma-1}\right)^{1-\sigma}
$$

and

$$
\pi_{0}^{I E}=m \pi_{0}^{I}=\frac{m Y}{\sigma}\left(\frac{\alpha c}{P} \frac{\sigma}{\sigma-1}\right)^{1-\sigma}=m \alpha^{1-\sigma} \pi_{0}
$$

Then it is straightforward to see that

$$
\pi_{0}^{I E}-\pi_{0}^{I}=\left(m \alpha^{1-\sigma}-\alpha^{1-\sigma}\right) \pi_{0}=\alpha^{1-\sigma}(m-1) \pi_{0}>(m-1) \pi_{0}=\pi_{0}^{E}-\pi_{0}
$$

and likewise

$$
\pi_{0}^{I E}-\pi_{0}^{E}=\left(m \alpha^{1-\sigma}-m\right) \pi_{0}=m\left(\alpha^{1-\sigma}-1\right) \pi_{0}>\left(\alpha^{1-\sigma}-1\right) \pi_{0}=\pi_{0}^{I}-\pi_{0}
$$

and with similar results for $\pi_{\gamma}^{I E}, \pi_{\gamma}^{E}$ and $\pi_{\gamma}^{I}$.

We now show that the incentive to invest in exporting in addition to innovation can be smaller than without previous innovation, despite the complementarity of the two activities. To see this we compare

$$
\begin{aligned}
E(\pi \mid I E)-E(\pi \mid I) & =\left(q-\delta_{L}-\delta_{I E}\right) \pi_{0}^{I E}+\left(1-q+\delta_{L}+\delta_{I E}\right) \pi_{\gamma}^{I E}-F_{E}-F_{I} \\
& -\left[\left(q-\delta_{L}-\delta_{I}\right) \pi_{0}^{I}+\left(1-q+\delta_{L}+\delta_{I}\right) \pi_{\gamma}^{I}-F_{I}\right] \\
& =q\left[\pi_{0}^{I E}-\pi_{0}^{I}\right]+(1-q)\left[\pi_{\gamma}^{I E}-\pi_{\gamma}^{I}\right]-\delta_{L}\left[\left(\pi_{0}^{I E}-\pi_{\gamma}^{I E}\right)-\left(\pi_{0}^{I}-\pi_{\gamma}^{I}\right)\right] \\
& -\delta_{I E}\left[\pi_{0}^{I E}-\pi_{\gamma}^{I E}\right]+\delta_{I}\left[\pi_{0}^{I}-\pi_{\gamma}^{I}\right]-F_{E}
\end{aligned}
$$

with

$$
\begin{aligned}
E(\pi \mid E)-E(\pi) & =\left(q-\delta_{L}-\delta_{E}\right) \pi_{0}^{E}+\left(1-q+\delta_{L}+\delta_{E}\right) \pi_{\gamma}^{E}-F_{E} \\
& -\left[\left(q-\delta_{L}\right) \pi_{0}+\left(1-q+\delta_{L}\right) \pi_{\gamma}\right] \\
& =q\left[\pi_{0}^{E}-\pi_{0}\right]+(1-q)\left[\pi_{\gamma}^{E}-\pi_{\gamma}\right] \\
& -\delta_{L}\left[\left(\pi_{0}^{E}-\pi_{\gamma}^{E}\right)-\left(\pi_{0}-\pi_{\gamma}\right)\right]-\delta_{E}\left[\pi_{0}^{E}-\pi_{\gamma}^{E}\right]-F_{E}
\end{aligned}
$$

Note that the former, given by (26), decreases more in $\delta_{L}$ than the latter, given by (27), since $\left(\pi_{0}^{I E}-\pi_{0}^{I}-\pi_{0}^{E}+\pi_{0}\right)>\left(\pi_{\gamma}^{I E}-\pi_{\gamma}^{E}-\pi_{\gamma}^{I}+\pi_{\gamma}\right)$, i.e. the complementarity is more pronounced, the lower the cost of financing, as follows from Assumption 1.

We now show by example that (26) can be smaller than (27) and that this is more likely to be the case the larger $\delta_{L}$. For this, consider the example where $\pi_{\gamma}=\pi_{\gamma}^{I}=\pi_{\gamma}^{E}=\pi_{\gamma}^{I E}=0$, i.e. external finance is prohibitively costly. Then (26) simplifies to

$$
\begin{aligned}
& \left(q-\delta_{L}\right)\left[\pi_{0}^{I E}-\pi_{0}^{I}\right]-\delta_{I E} \pi_{0}^{I E}+\delta_{I} \pi_{0}^{I}-F_{E} \\
\leq \quad & \left(q-\delta_{L}\right)\left[\pi_{0}^{I E}-\pi_{0}^{I}\right]-\delta_{E} \pi_{0}^{I E}-\delta_{I}\left(\pi_{0}^{I E}-\pi_{0}^{I}\right)-F_{E}
\end{aligned}
$$


using $\delta_{I E} \geq \delta_{I}+\delta_{E}$. Furthermore, (27) simplifies to

$$
\left(q-\delta_{L}\right)\left[\pi_{0}^{E}-\pi_{0}\right]-\delta_{E} \pi_{0}^{E}-F_{E} .
$$

We now see that it is possible that(28) is smaller than (29) (while (29) still being positive) if

$$
\begin{aligned}
\left(q-\delta_{L}\right)\left[\pi_{0}^{I E}-\pi_{0}^{I}\right]-\delta_{E} \pi_{0}^{I E}-\delta_{I}\left(\pi_{0}^{I E}-\pi_{0}^{I}\right)-F_{E} & <\left(q-\delta_{L}\right)\left[\pi_{0}^{E}-\pi_{0}\right]-\delta_{E} \pi_{0}^{E}-F_{E} \\
\left(q-\delta_{L}\right)\left[\pi_{0}^{I E}-\pi_{0}^{I}-\pi_{0}^{E}+\pi_{0}\right]-\delta_{E}\left[\pi_{0}^{I E}-\pi_{0}^{E}\right] & <\delta_{I}\left[\pi_{0}^{I E}-\pi_{0}^{I}\right]
\end{aligned}
$$

Note that the left hand side decreases in $\delta_{L}$. Note further that for parameters such that (29) is positive, the left hand side is positive as well. However, the smaller sign holds for $\delta_{I}$ sufficiently large. 